\title{
Copepod herbivory rate in a large arctic polynya and its relationship to seasonal and spatial variation in copepod and phytoplankton biomass
}

\author{
P. A. Saunders ${ }^{1,3, *}$, D. Deibel ${ }^{1}$, C. J. Stevens ${ }^{1}$, R. B. Rivkin ${ }^{1}$, S. H. Lee ${ }^{1}$, B. Klein ${ }^{2}$ \\ ${ }^{1}$ Ocean Sciences Centre, Memorial University, St. John's, Newfoundland A1C 5S7, Canada \\ ${ }^{2}$ GIROQ, Department of Biology, Université Laval, Sainte-Foy, Québec G1K 7P4, Canada \\ ${ }^{3}$ Present address: Department of Biology, Ashland University, Ashland, Ohio 44805, USA
}

\begin{abstract}
Large copepod species (Calanus spp.) overwinter in the North Water Polynya (NOW; $~ 75$ to $79^{\circ} \mathrm{N}, \sim 68$ to $78^{\circ} \mathrm{W}$ ) and, via upward migration, can potentially exert a rapid and important grazing impact on the spring phytoplankton bloom. This study investigated the pattern and factors controlling copepod herbivory in the NOW from April through July 1998. Typically, there was a chlorophyll maximum between $50 \mathrm{~m}$ and the surface. We used incubation experiments to measure weight-specific herbivory rates ( 0 to $0.24 \mu \mathrm{gC} \mu \mathrm{g} \mathrm{C}^{-1} \mathrm{~d}^{-1}$ ) representing the average for surface-layer copepod assemblages at each station, and we quantified 0 to $50 \mathrm{~m}$ in situ copepod biomass (20 to $3200 \mathrm{mg} \mathrm{C} \mathrm{m}^{-2}$ ). Weight-specific herbivory rate was positively related to initial chlorophyll a concentration in experiments $\left(\mathrm{r}^{2}=0.54\right)$. Maximum in situ copepod herbivory rate and in situ copepod biomass were larger and peaked earlier at stations dominated by Baffin Bay water in the southern and eastern NOW versus stations dominated by silica-rich arctic water in the northern and western NOW. We used a standard scaling model $\left(I=a \mathrm{~W}^{b}\right)$, where $I=$ maximum daily ingestion rate and $\mathrm{W}=$ individual weight, to test the potential effect of size bias on our estimates of total in situ copepod herbivory, because the size structures of experimental and in situ copepod assemblages were often statistically different. Although these calculations found up to $\pm 40 \%$ difference in our estimate of total in situ copepod herbivory, this had very little effect on the estimates of copepod impact on daily primary production $( \pm 1 \% \mathrm{PP})$, because copepod biomass was usually low relative to NOW phytoplankton biomass and productivity. During pre-bloom and spring-bloom conditions, total in situ copepod herbivory was low ( $<10 \%$ of PP). After the spring diatom bloom, we measured higher removal rates ( 15 and $55 \%$ of PP) at 2 southern stations, where copepod biomass was high and PP was relatively low.
\end{abstract}

KEY WORDS: Arctic $\cdot$ Polynya $\cdot$ Copepod $\cdot$ Herbivory $\cdot$ Size structure $\cdot$ Plankton food web $\cdot$ Seasonal variation $\cdot$ Spatial variation

\section{INTRODUCTION}

The North Water Polynya (NOW; $\sim 75$ to $79^{\circ} \mathrm{N}, \sim 68$ to $78^{\circ} \mathrm{W}$ ) is one of the largest of arctic polynyas and is a productive region with abundant bird and mammal populations (Stirling 1997). The NOW is dynamic and the seasonal extent of its open water (max. $\sim 90000 \mathrm{~km}^{2}$ ) is bounded by Canada, Greenland, and regions of thick pack ice $(>2 \mathrm{~m})$. The extensive ice-free periods of polynyas are associated with increased annual primary productivity (Rysgaard et al. 1999). Dominant zooplankton (e.g. pelagic tunicates, copepods) determine the amount of primary production transfered to vertebrate planktivores, contribute to seasonal shifts in plankton food-web structure, and may alter carbon export to the benthos. This study was part of a project investigating zooplankton links between the physical processes that form and maintain the polynya and planktonic food-web processes in the NOW. Specifically, this study quantified seasonal and 
water-mass-associated variation in total in situ copepod herbivory rate.

In arctic waters, Calanus spp. often dominate copepod biomass, and their large $(\sim 3$ to $7 \mathrm{~mm})$, late-copepodite stages overwinter at intermediate depths (e.g. Dale et al. 1999). A previous study of NOW copepods confirmed the overwintering habit of Calanus spp. populations (Tidmarsh 1973). Variability in total grazing flux is most commonly identified where there are large temporal or spatial differences in predator biomass or size structure (e.g. Hirche et al. 1991, 1994, Bautista et al. 1992). Consequently, arctic copepod populations have the potential for a rapid trophic response to spring diatom production via upward migration and may be relatively efficient consumers of large-celled spring phytoplankton (Krause \& Trahms 1983, Eilertsen et al. 1989, Bathmann et al. 1990). In contrast, copepods increase to a seasonal maximum sometime after the spring diatom bloom, where cold seas are dominated by smaller coastal species (Nielsen \& Richardson 1989, Gowen et al. 1999).

Our primary objective was to describe the seasonal and spatial pattern of herbivory by surface-layer copepod assemblages, estimated from (1) chlorophyll a removal rates quantified in shipboard incubation experiments and (2) measurements of in situ copepod biomass. We hypothesized that weight-specific herbivory rates of copepods would correspond primarily to food availability, as temperature varies relatively little in polar regions (cf. Huntley \& Lopez 1992, Hansen et al. 1997). We also expected total in situ herbivory rates to vary seasonally and spatially with composition and biomass of the copepod assemblage. Our secondary objective was to test the effect of copepod size versus specific-rate relationships on our estimates of total in situ copepod herbivory rate. We used model-sensitivity analysis to quantify potential estimation error due to size structure differences between experimental and in situ copepod assemblages. We discuss the grazing impact of copepods on the NOW spring diatom bloom, evaluate the relationship of herbivory rates and the dominant surface-water masses, and summarize our inferences from these results with regard to carbon export to higher trophic levels and the benthos.

\section{MATERIALS AND METHODS}

In situ characteristics of surface layer. We organized experiments by dominant surface-water masses. Tremblay et al. (2002) used silicate-salinity relationships in the upper $50 \mathrm{~m}$ to distinguish silica-rich arctic water (SRAW) and Baffin Bay water (BBW); transitional water (MIX) occurred where there was mixing of SRAW and BBW. For each experimental station, we calculated mean water-column temperature from 0 to $50 \mathrm{~m}$ profile data (values interpolated at $1 \mathrm{~m}$ intervals). We estimated phytoplankton biomass $\left(\mathrm{mg} \mathrm{C} \mathrm{m}^{-2}\right.$; 0 to $50 \mathrm{~m}$ water column) by integration of chlorophyll a profiles generated by Klein et al. (2002), who used a modification of the method of Knap et al. (1996), and a carbon:chlorophyll a ratio of 50 (consistent with NOW field data, April to June 1998; Z. P. Mei pers. comm.)

Zooplankton samples were collected by vertical tows of a $6 \mathrm{~m}$ long, Nitex-mesh plankton net $(200 \mu \mathrm{m}$ mesh, $1 \mathrm{~m}^{2}$, square-mouth; or $300 \mu \mathrm{m}$ mesh, $0.785 \mathrm{~m}^{2}, 1 \mathrm{~m}$ diameter). Net tows represented surface or middle strata, whose depth varied according to the local fluorescence profile (see third subsection of 'Results'). We retrieved nets at 0.3 to $0.5 \mathrm{~m} \mathrm{~s}^{-1}$. Samples for quantification of in situ copepod assemblages were rinsed into the codend, concentrated, and preserved in $4 \%$ formalin. We used a Motoda box splitter or Hensen-Stemple pipette to make fractions of the original sample, and we enumerated copepods by species and stage. In situ abundance was calculated using tow-volume estimates determined from net dimensions, flow-meter values, and tow depths. We also categorized each species/ stage group as 'large' or 'small,' using data from 6 experiments, for which we divided the copepod treatment using a coarse sieve (see following subsection).

We subsampled 'live' tows (see following subsection) for copepod CHN analysis; the copepods were incubated in filtered seawater for up to $24 \mathrm{~h}$, filtered at $<5000 \mathrm{~Pa}$, and stored at $-80^{\circ} \mathrm{C}$. Using several samples from April and July, we sorted individuals from dominant species/stage groups, measured carapace length, and quantified carbon with a Perkin Elmer 2400 elemental analyzer. We used the following model (Model 1 regression: SAS Institute 1990) to estimate each individual's biomass $\left(\mathrm{C}=\mu \mathrm{g} \mathrm{C}\right.$ ind.$^{-1}$, length $=\mathrm{mm}, \mathrm{r}^{2}=0.76, \mathrm{n}=63$; 11 species/stage groups, 1.9 to $7.2 \mathrm{~mm}$ ):

$$
\begin{gathered}
\ln C=1.19( \pm 0.68)+4.99( \pm 1.04) \times \\
{[\ln (\text { length })]-1.07( \pm 0.38) \times\left[(\ln [\text { length }])^{2}\right]}
\end{gathered}
$$

Herbivory rates. To determine weight-specific herbivory rates for copepod assemblages, we did shipboard incubation experiments using water and copepods from 6 to 14 stations each month (April, May, June and July 1998). Experiments represented stations extending along the eastern and western edges of the polynya, and additional central stations in the broader southern region of the polynya (see Fig. 1). All experiments were done at stations that were a sub-set of the 84-station NOW sampling grid (Bâcle et al. 2002).

We collected water for incubations from 1 or 2 discrete depths using a rosette fitted with $10 \mathrm{l}$ Brookes Ocean Technology bottles, a Falmouth Scientific Instruments ICTD profiler (integrated conductivity, temperature, and depth), and a Seatech fluorometer. We chose 
prey-water sampling depth(s) using the in situ, relative-fluorescence profile. One depth represented the chlorophyll maximum, if detectable (Table 1). At 14 stations, we sampled a second depth to represent conditions below the highchlorophyll layer (results of these 14 experiments are summarized in 'Results', but the data are not included in the tables). Each 101 sample was transferred gently via silicone tubing into a polyethylene cubitainer, and transported to a dark, $\sim 0^{\circ} \mathrm{C}$ container laboratory. 'Live' net tows were collected in replicate with the quantitative samples, except in April (see Tables 1 \& 2). 'Live' nets were not rinsed; codend contents were immediately and gently diluted in 201 of surface water. Copepods were transferred into 201 of rosette-collected incubation water using a $300 \mu \mathrm{m}$-mesh sieve cup. We allowed copepods to acclimate for 2 to $24 \mathrm{~h}$ in the cold laboratory.

With minimum light, we set up experiments with 2 control (no copepods added) and 3 treatment (copepods added) bottles per prey-water depth. Water was mixed by inversion, then distributed by silicone tubing to 41 polycarbonate bottles and 5 sets of corresponding time-zero $\left(t_{0}\right)$ samples. Control bottles were filled, sealed with parafilm, and capped. Treatment bottles were filled to within 100 to $200 \mathrm{ml}$ of the top before we added copepods (usually 4 to 10 individuals $\mathrm{l}^{-1}$ ) and finished as for controls. We harvested copepods with a $300 \mu \mathrm{m}-\mathrm{mesh}$ sieve and a wide-bore pipette, in which we inspected them and did preliminary counts against a lowintensity back-light; 6 experiments measured rates for 'large' and 'small' fractions of the copepod assemblage, defined by a second sieve (nylon window screen, $1300 \times 1050 \mu \mathrm{m}$-mesh).

The bottles were rotated continuously on a plankton wheel at $\sim 1.5 \mathrm{rpm}$ for 24 or $48 \mathrm{~h}$ in the dark. Our goal was 20 to $80 \%$ removal of chlorophyll a during each incubation. Time-final $\left(t_{f}\right)$ water samples were collected by gravity, with $300 \mu \mathrm{m}$ Nitex mesh attached to the inflow of the silicone siphon in order to retain treatment copepods for quantification. The copepods were rinsed onto a
Table 1. Specifications of copepod grazing experiments in North Water Polynya (April to July 1998). Dominant water-mass abbreviations defined as in Tremblay et al. (2002): SRAW: silica-rich arctic water; BBW: Baffin Bay water; Mix: transitional water (mixing of SRAW and BBW); SRAW + MIX: combined data for SRAW and MIX stations; $\mathrm{BBW}_{\text {cold: }}$ Baffin Bay water,$<1^{\circ} \mathrm{C}_{i}$ Prey depth: prey water depth $(\mathrm{m}) ; t_{0}[\mathrm{chla}]$ : average and CV initial chlorophyll a concentration $(\mu \mathrm{g} \mathrm{chl}$ $a \mathrm{l}^{-1}$ ); Net tow depth: net tow depth (range in $\mathrm{m}$ ) for experimental copepods; Cop. biomass: average and $\mathrm{CV}$ copepod biomass during experiments ( $\mathrm{mg} \mathrm{C}^{-1}$ ); L, S: large-copepod and small-copepod fractions, respectively

\begin{tabular}{|c|c|c|c|c|c|c|c|}
\hline \multirow{2}{*}{$\begin{array}{l}\text { Water mass } \\
\text { Stn }\end{array}$} & \multirow{2}{*}{$\begin{array}{l}\text { Date } \\
(1998)\end{array}$} & \multirow{2}{*}{$\begin{array}{l}\text { Prey } \\
\text { depth }\end{array}$} & \multicolumn{2}{|c|}{$t_{0}[\mathrm{chl} a]$} & \multirow{2}{*}{$\begin{array}{l}\text { Net tow } \\
\text { depth }\end{array}$} & \multicolumn{2}{|c|}{ Cop. biomass } \\
\hline & & & avg. & $\mathrm{CV}$ & & avg. & $\mathrm{CV}$ \\
\hline \multicolumn{8}{|l|}{ SRAW + MIX } \\
\hline \multirow[t]{2}{*}{2} & $14 \mathrm{Apr}$ & 75 & 0.031 & 23 & $600-150$ & $24(\mathrm{~L})$ & 17 \\
\hline & & & & & & $21(\mathrm{~S})$ & 27 \\
\hline \multirow[t]{2}{*}{22} & $17 \mathrm{Apr}$ & 50 & 0.046 & 19 & $400-0$ & $5.1(\mathrm{~L})$ & 7 \\
\hline & & & & & & $3.7(\mathrm{~S})$ & 1 \\
\hline \multirow[t]{2}{*}{44} & $21 \mathrm{Apr}$ & 50 & 0.049 & 27 & $385-0$ & $3.7(\mathrm{~L})$ & 11 \\
\hline & & & & & & $3.0(\mathrm{~S})$ & 12 \\
\hline \multicolumn{8}{|l|}{ BBW } \\
\hline \multirow[t]{2}{*}{49} & 23 Apr & 26 & 0.11 & 6 & $460-0$ & $3.5(\mathrm{~L})$ & 38 \\
\hline & & & & & & 5.9 (S) & 20 \\
\hline 27 & 27 Apr & 35 & 0.39 & 7 & $75-0$ & 4.8 & 36 \\
\hline 40 & 02 May & 20 & 1.4 & 32 & $50-0$ & 0.75 & 18 \\
\hline \multicolumn{8}{|l|}{ SRAW + MIX } \\
\hline 2 & 09 May & 20 & 0.53 & 5 & $50-0$ & 1.2 & 45 \\
\hline \multirow[t]{2}{*}{27} & 17 May & 40 & 0.58 & 6 & $150-0$ & $3.0(\mathrm{~L})$ & 2 \\
\hline & & & & & & $0.81(\mathrm{~S})$ & 20 \\
\hline 22 & 18 May & 100 & 0.12 & 18 & $150-0$ & 0.26 & 85 \\
\hline 44 & 28 May & 30 & 4.4 & 2 & $75-0$ & 0.47 & 43 \\
\hline 31 & 29 May & 20 & 2.6 & 9 & $50-0$ & 0.65 & 62 \\
\hline \multicolumn{8}{|l|}{ BBW } \\
\hline 40 & 25 May & 25 & 3.2 & 18 & $50-0$ & 1.6 & 23 \\
\hline 54 & 26 May & 15 & 14 & 12 & $50-0$ & 5.2 & 7 \\
\hline \multicolumn{8}{|l|}{ SRAW + MIX } \\
\hline \multirow[t]{2}{*}{2} & 07 Jun & 37 & 0.31 & 15 & $50-0$ & $2.1(\mathrm{~L})$ & 18 \\
\hline & & & & & & $0.06(\mathrm{~S})$ & 48 \\
\hline 14 & 10 Jun & 15 & 7.6 & 8 & $55-0$ & 0.30 & 32 \\
\hline 27 & 12 Jun & 15 & 7.8 & 3 & $30-0$ & 0.11 & 26 \\
\hline 22 & 14 Jun & 15 & 2.9 & 7 & $50-0$ & 0.16 & 64 \\
\hline 31 & 15 Jun & 15 & 4.6 & 38 & $50-0$ & 0.24 & 27 \\
\hline 60 & 25 Jun & 4 & 3.5 & 8 & $25-0$ & 0.86 & 8 \\
\hline \multicolumn{8}{|l|}{ BBW } \\
\hline 54 & 05 Jun & 11 & 4.2 & 9 & $50-0$ & 3.5 & 19 \\
\hline 49 & 05 Jun & 20 & 10 & 10 & $50-0$ & 1.9 & 40 \\
\hline 40 & 19 Jun & 15 & 10 & 6 & $20-0$ & 0.73 & 16 \\
\hline 54 & 22 Jun & 35 & 1.9 & 7 & $75-0$ & 2.0 & 34 \\
\hline 50 & 22 Jun & 20 & 7.5 & 4 & $75-0$ & 0.44 & 11 \\
\hline 44 & 24 Jun & 21 & 5.3 & 14 & $25-0$ & 1.2 & 37 \\
\hline \multicolumn{8}{|l|}{$\mathrm{BBW}_{\text {cold }}$} \\
\hline 68 & 26 Jun & 41 & 0.46 & 5 & $75-0$ & 1.2 & 52 \\
\hline 82 & 27 Jun & 31 & 0.49 & 5 & $75-0$ & 2.6 & 6 \\
\hline SRAW + MIX & & & & & & & \\
\hline 2 & $13 \mathrm{Jul}$ & 15 & 4.2 & 12 & $75-0$ & 0.54 & 30 \\
\hline BBW & & & & & & & \\
\hline 68 & $01 \mathrm{Jul}$ & 50 & 0.66 & 6 & $75-0$ & 2.2 & 14 \\
\hline 50 & $05 \mathrm{Jul}$ & 40 & 2.9 & 7 & $75-0$ & 0.80 & 39 \\
\hline 44 & $09 \mathrm{Jul}$ & 33 & 1.5 & 11 & $60-0$ & 0.62 & 69 \\
\hline 1 & $16 \mathrm{Jul}$ & 11 & 4.8 & 8 & $40-0$ & 0.32 & 27 \\
\hline 40 & $17 \mathrm{Jul}$ & 13 & 0.99 & 15 & $50-0$ & 0.79 & 1 \\
\hline 35 & $19 \mathrm{Jul}$ & 8 & 2.6 & 14 & $100-0$ & 0.58 & 47 \\
\hline 54 & $21 \mathrm{Jul}$ & 20 & 1.5 & 24 & $80-0$ & 0.68 & 41 \\
\hline
\end{tabular}


$300 \mu \mathrm{m}$ Nitex sieve, collected on a $45 \mathrm{~mm}$ GF/C filter under low $(<5000 \mathrm{~Pa})$ vacuum, quick-frozen on an aluminum block (ca. $-80^{\circ} \mathrm{C}$ ), and stored at $-80^{\circ} \mathrm{C}$.

Quantification: We collected samples (200 to $510 \mathrm{ml}$ ) for analyses of chlorophyll $a$ and pheopigments on $25 \mathrm{~mm} \mathrm{GF} / \mathrm{F}$ filters and stored them at $-80^{\circ} \mathrm{C}$ until post-cruise processing. We used $90 \%$ acetone to extract pigments overnight at $-20^{\circ} \mathrm{C}$, and determined fluorescence values using a Turner Designs Model 10 fluorometer.

We processed experimental copepod samples in a stratified (month, location) sequence, to avoid seasonal or spatial bias in fecal pellet observations. We thawed samples in a few milliliters of water and enumerated all copepods to species and stage. We measured carapace length, usually to the nearest $40 \mu \mathrm{m}$. In a few cases we stopped measuring abundant groups $(\mathrm{n}>40)$ and applied the sample-average length to counted individuals. We estimated treatment biomass using the same empirical model applied to in situ samples (see first subsection).

We noted the presence $(n \geq 10)$ or absence of fecal pellets in treatment samples and noted pellet color(s). After sorting copepods by carapace length into $0.5 \mathrm{~mm}$ bins, we used the Kolmogorov-Smirnov 2-sample test to determine similarity of the copepod size-frequency distribution among treatment replicates (Sokal \& Rohlf 1995, p. 434).

Analysis: We assessed treatment effects with a general linear model that compared daily chlorophyll $a$ change $\left(t_{f}-t_{0}\right)$ in control versus copepod-addition bottles $(\alpha=0.1$, due to low power of design). With these data we calculated clearance rate for each bottle (Frost 1972). Chlorophyll a was converted to carbon units (C:chl $a=50)$, and clearance rates were normalized by the respective bottle's treatment biomass to calculate weight-specific herbivory rate. We calculated the average rate for each experiment, but only if 2 or 3 replicate treatment bottles showed net removal of chlorophyll $a_{i}$ otherwise, we report the weight-specific herbivory rate as zero (see Table 3 ). We also deleted a single replicate with no net chlorophyll removal from 6 experiments, each with positive removal in the remaining 2 replicates (see Table 3: April: Stns $2 \mathrm{~S}$ and 22L; June: Stns 31 and 82; July: Stns 2 and 50).

Extrapolation of experimental to in situ rate: We estimated total in situ copepod herbivory rate $\left(\mathrm{d}^{-1}\right)$ for the 50-to-0 $\mathrm{m}$ water column as the product of in situ copepod biomass $\left(\mathrm{m}^{-2}\right)$ and average weight-specific herbivory rate. For experiments with 'Large' and 'Small' copepod assemblages, we summed separate calculations for each treatment.

We used the Kolmogorov-Smirnov 2-sample test to compare the size distributions of copepods in experimental bottles with corresponding in situ samples.
Other studies have sometimes reported a relationship between copepod body size and specific ingestion rate (see 'Introduction'); we applied a scaling model to assess potential differences in our estimate of total copepod herbivory due to size structure changes between experiments and in situ assemblages. Each size-weighted specific rate depends on (1) the exponential coefficient of the scaling model, (2) the size structure of the experimental copepod assemblage, and (3) the total chlorophyll removal rate. We parameterized a scaling model $I=W^{b}$, where $I=$ maximum daily ingestion rate $\left(\mu \mathrm{gC} \mu \mathrm{C} \mathrm{C}^{-1} \mathrm{~d}^{-1}\right), W=$ individual weight $(\mu \mathrm{gC})$ and $b=$ constant $\left(\mu \mathrm{g} \mathrm{C}^{-1} \mathrm{~d}^{-1}=0,-0.1\right.$, -0.2 , or -0.3 ) (the empirical model of Hansen et al. 1997 showed $b$ as -0.23 ) to calculate a weighting coefficient $\left(W C_{i}\right)$ for each size of copepod in a treatment:

$$
W C_{\mathrm{i}}=I_{\mathrm{i}} /\left(I_{1}+I_{2}+\ldots+I_{\mathrm{n}}\right)
$$

where $i=$ size of each copepod in the bottle, $\mathrm{n}=$ total number of size-groups in the bottle, and $I_{\mathrm{i}}=$ predicted daily herbivory rate for each size group $\left(I_{\mathrm{i}}=W_{\mathrm{i}}{ }^{b}\right)$. Next, we used $W C_{i}$ values to calculate a scaling factor $\left(\mathrm{SF}_{\text {size-group }}\right)$ to represent the proportional ingestion by each size-group:

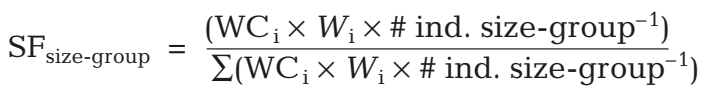

Finally, we calculated a size-weighted estimate of specific rate $\left(\mathrm{SHR}_{\text {scaled estimate }}\right)$ for each size-group in a treatment bottle:

$$
\mathrm{SHR}_{\text {scaled estimate }}=\frac{\begin{array}{l}
\text { total phytoplankton-carbon } \\
\text { removal }\left(\mathrm{mg} \mathrm{C} \mathrm{l}^{-1} \mathrm{~d}^{-1}\right) \times S F_{\text {size-group }}
\end{array}}{W_{\mathrm{i}} \times \# \text { ind. size-group }{ }^{-1} \mathrm{l}^{-1}}
$$

We estimated linear regression parameters (Model I) for each treatment assemblage $\left[\ln \left(\mathrm{SHR}_{\text {scaled estimate }}\right)=\right.$ $Y$-int + slope $\times \ln (W)]$. The slope was constant $(b)$, because it was derived from the original scaling model $(0,-0.1,-0.2$, or -0.3$)$. The $Y$-intercept was variable. We used the mean parameter values for each experiment to predict specific rates for 1, 3, and $5 \mathrm{~mm}$ 'standard-length' copepods. We calculated size-scaled estimates of total in situ copepod herbivory rate using the specific rate for each in situ size group and in situ sizefrequency data.

\section{RESULTS}

\section{In situ characteristics of surface layer}

SRAW was dominant in May, BBW was dominant in July, and the 2 water masses had a more intermediate influence in April and June (Fig. 1). Comparison of 50 versus $100 \mathrm{~m}$ integrations showed that BBW spread as 
a shallow layer over depths more influenced by SRAW at southwestern stations (Stns 44 and 50).

Overall, the mean surface-layer temperature of BBW stations (mean $\pm \mathrm{SD}=-0.88 \pm 0.63^{\circ} \mathrm{C}$ ) was higher than that of SRAW + MIX stations $\left(-1.45 \pm 0.31^{\circ} \mathrm{C}_{i}\right.$ Student's $t$-test, unequal variance: $\mathrm{p}=0.003, \mathrm{df}=17,14)$ (Fig. 2a,b); monthly differences varied: April, $\mathrm{p}=0.14$; May, $p=0.02$; June, $p=0.04$; July, not testable. Earliest warming was at eastern stations (Stns 40 and 27); greatest warming was at central and southwestern stations, all of which were usually BBW stations $\left(\sim 1\right.$ to $2^{\circ} \mathrm{C}$ increase at Stns 35, 40,44, 49 and 50, in April to July; data not shown). Maximum in situ temperature at the depth of prey-water sampling was $1.4^{\circ} \mathrm{C}$.

Overall, phytoplankton biomass (Fig. 2c,d) was not significantly different between BBW (mean \pm SD $=$ $9439 \pm 8446 \mathrm{mg} \mathrm{C} \mathrm{m}^{-2}$ ) and SRAW + MIX stations (5830 $\pm 6555 \mathrm{mg} \mathrm{C} \mathrm{m}^{-2}$ ). However, the pattern of integrated chlorophyll a concentration demonstrates a phytoplankton bloom that developed during May in the southeast, June at central stations, and July in the north. In April, there was low phytoplankton biomass $\left(<1000 \mathrm{mg} \mathrm{C} \mathrm{m}^{-2}\right)$, except in the eastern polynya (1000 to $5000 \mathrm{mg} \mathrm{C} \mathrm{m}^{-2}$; Stns 40 and 27). In May, southern stations showed high concentrations (5000 to 26000 $\mathrm{mg} \mathrm{C} \mathrm{m}{ }^{-2}$; Stns 40, 44 and 54), but all other stations had moderate biomass (1000 to $5000 \mathrm{mg} \mathrm{C} \mathrm{m}^{-2}$ ). In June, most stations showed high phytoplankton concentration, but biomass remained moderate in the northwest (Stn 2) and declined to moderate levels at open-water stations in the south (Stn 44,54). In July, Stn 2 showed high biomass (7855 $\mathrm{mg} \mathrm{C} \mathrm{m}^{-2}$ ), most stations had decreased to moderate values, and southern stations remained similar to June values (Stns 44 and 54).

Once phytoplankton biomass increased in an area of the polynya, copepod biomass was often more concentrated in the surface than the middle water column, including $80 \%$ of BBW stations (Table 2). Median biomass ratios for surface versus middle strata were 0.4 (April, $\mathrm{n}=5), 1.5$ (May, $\mathrm{n}=5$ ), 2.0 (June, $\mathrm{n}=$ 9), and 2.5 (July, $\mathrm{n}=7$ ). BBW stations had higher copepod biomass ( 0 to $50 \mathrm{~m}$ water column; mean \pm SD $=1212 \pm 905 \mathrm{mg} \mathrm{C} \mathrm{m}^{-2}$ ) than SRAW + MIX stations $\left(261 \pm 359 \mathrm{mgC} \mathrm{m}^{-2} ;\right.$ Fig. 2e, $\mathrm{f}_{;}$Student's $t$-test, unequal variance: $p=0.002, d f=17,13)$, but monthly differences were not strong: April, $p=0.29$; May $p=$ 0.29 ; June $p=0.09$; July not testable. In May (Table 2), surface-layer copepod biomass increased by an order of magnitude in the southeast ( $>500$ to $3200 \mathrm{mg} \mathrm{C} \mathrm{m}^{-2}$; Stns 40 and 54). In June, similarly high concentrations of copepod biomass extended to east-central and southern stations (Stns 27, 40, 44, 49, 50, 54a, 54b, 68 and 82) as well as 1 northern station (2). In July, copepod biomass remained high in those regions (Stns 1, 35, 44, 50 and 68), except for a decrease in the southeast (Stns 40 and 54); we have no July data for west-central stations.

Maximum 'large' copepod biomass occurred in May (SRAW + MIX and BBW stations), reflecting general seasonal changes in the composition of surface-layer copepod assemblages (Fig. 3). 'Large' copepods included Calanus hyperboreus IV to VI, C. glacialis V and VI, C. finmarchicus $\mathrm{V}$ and $\mathrm{VI}$, and Metridia spp. $\mathrm{VI}_{\text {femalesi }}$ 'small' copepods included C. hyperboreus I to III, C. glacialis I to IV, C. finmarchicus I to IV, and Metridia I to $\mathrm{VI}_{\text {males. The }}$ absolute biomass of later-stage $C$. glacialis and $C$. finmarchicus (IV-VI) was approximately constant (monthly median 1.7 to $3.5 \mathrm{mg} \mathrm{C} \mathrm{m}^{-2}$ ), except that their abundance was lower at some SRAW-dominated stations. However, in May and June we did observe an increase in the absolute and relative biomass of late-stage C. hyperboreus (IV-VI; Fig. 4) in the southern polynya (Stns 40, 44, 49 and 54), at ice-covered stations (Stns 68 and 82), and in the northwest (Stn 2); both biomass measures decreased in July. Further, during June and July there was a strong increase in absolute and relative bio-

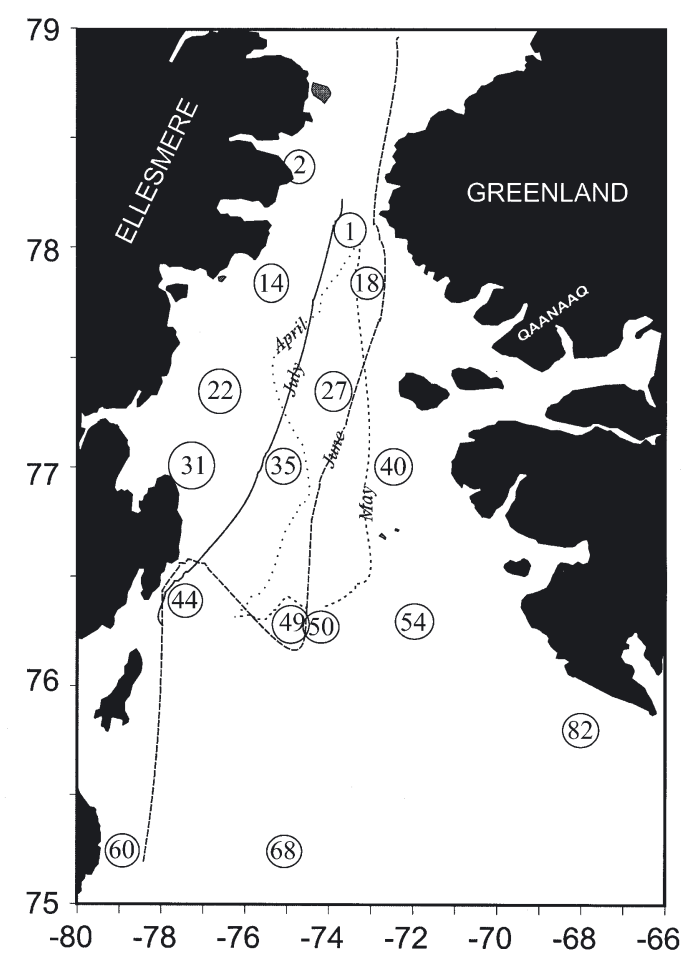

Fig. 1. Sampling stations in North Water Polynya, where we conducted copepod incubation experiments to determine weight-specific herbivory rate. Variable extent of Baffin Bay water (BBW) in upper $50 \mathrm{~m}$ is indicated by 4 differently patterned lines drawn through sampling grid. These isolines delimit surface-layer water masses (redrawn from Tremblay et al. 2002). For each month (April to July), stations located east and south of a line were predominantly influenced by BBW, whereas stations west and north of a line were dominated by silica-rich arctic water or a mixture with BBW (see 'Results') 

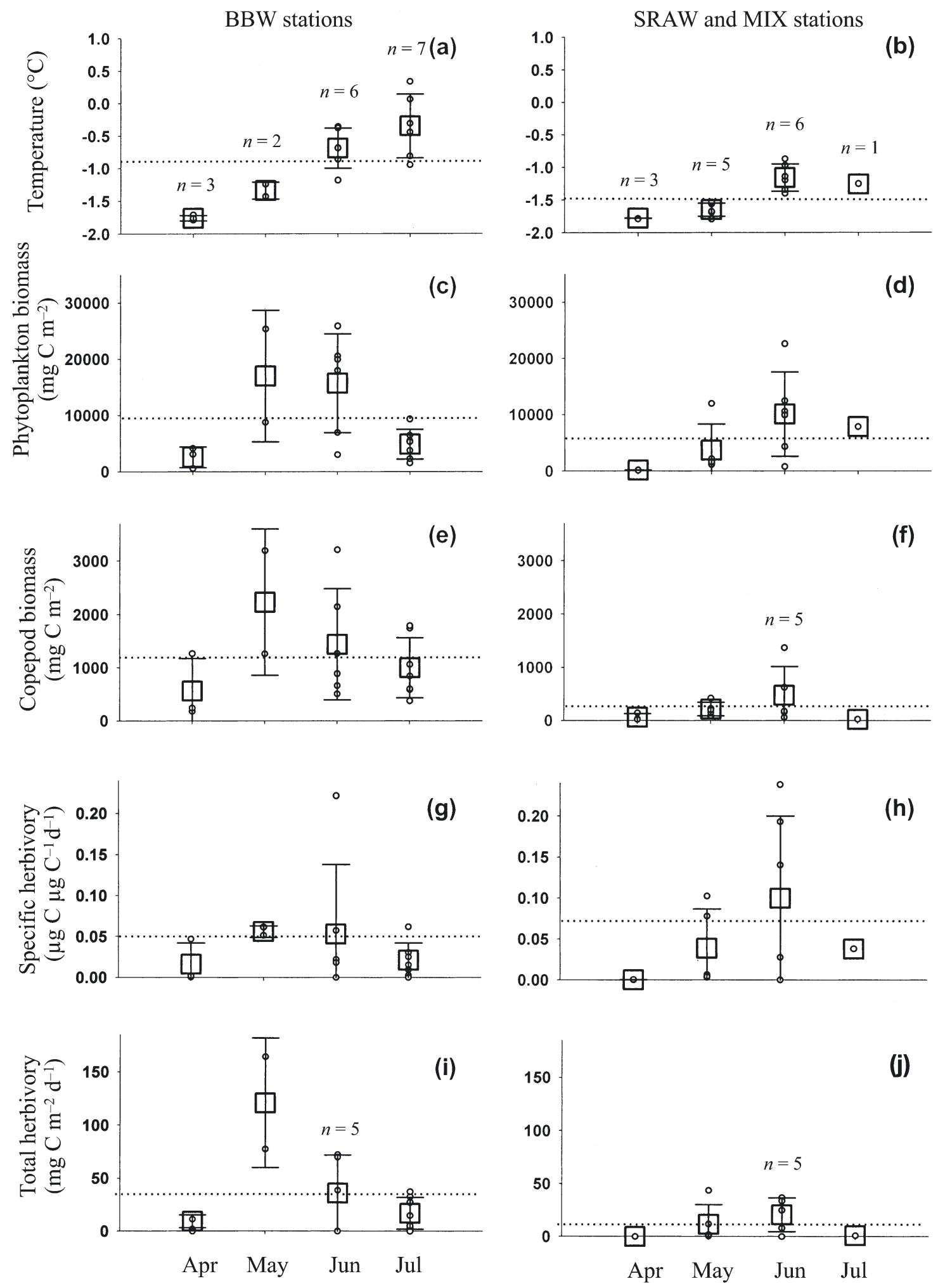

Fig. 2. Summary of 0 to $50 \mathrm{~m}$ data for (a), (b) average temperature; (c), (d) phytoplankton biomass; (e), (f) copepod biomass; (g), (h) weight-specific herbivory rate for experimental copepods; and (i), (j) total herbivory rate calculated for in situ copepods, 0 to $50 \mathrm{~m}\left(\mathrm{BBW}_{\text {cold }}\right.$ stations excluded here). (o) individual data-points; large squares and error bars are station averages \pm 1 SD. Sample size (n) for each mean is given in (a) and (b) with exceptions indicated. Dotted horizontal lines represent overall mean for each 
mass of early-stage Calanus copepodites (I-III; Fig. 4), except in the northwest (Stns 2 and 14) and at ice-covered stations (Stns 68 and 82).

Mean copepod biomass was loosely coupled to mean phytoplankton biomass, with stations grouped by watermass and month (Figs. 2c-f \& 5). One exception was that phytoplankton biomass at BBW stations decreased significantly between June and July (mean = 15687 vs 4850 mg C m ${ }^{-2}$; Tukey's HSD test: $\mathrm{p}<0.05)$, whereas copepod biomass did not (mean = 1445 vs 999 mg C $\left.\mathrm{m}^{-2} ; \mathrm{p}>0.05\right)$. There were also differences between the 2 water masses. BBW stations showed an earlier peak and larger accumulation of phytoplankton and copepod biomass than did SRAW + MIX stations. BBW stations also had a larger copepod stock per unit phytoplankton (median ratio $=0.15$ ) than did SRAW + MIX stations (0.075: Fig. 5).

\section{Herbivory rates}

Weight-specific herbivory rates were $<0.01$ to $0.24 \mu \mathrm{g} \mathrm{C} \mu \mathrm{g} \mathrm{C}^{-1} \mathrm{~d}^{-1}$ for copepod assemblages incubated with prey from the fluorescence maximum (Table 3). Chlorophyll removal in treatment bottles was statistically significant ( $p<0.1$ ) in 14 of 35 experiments (40\%). Another 14 experiments (40\%) suggested net removal of chlorophyll-containing prey cells, but higher replicate variance and/or lower removal rate may have occluded statistical significance in some cases (Table 3 ). These non-significant experiments included 7 in July with copepod fecal pellets in treatment bottles, an indication of active feeding. However, of those experiments with no net removal of chlorophyll a (20\%), 4 also had fecal pellets.

There were copepod fecal pellets in 21 of 23 experiments with phytoplankton biomass $>50 \mu \mathrm{g} \mathrm{Cl}^{-1}$ (= $1 \mu \mathrm{g} \mathrm{chl} \mathrm{a}{ }^{-1}$; Tables 1 \& 3). We did not observe fecal pellets in the 12 experiments with phytoplankton biomass $<50 \mu \mathrm{g} \mathrm{Cl}^{-1}$. Fecal pellets were abundant in July experiments, when we did not measure any statistically significant chlorophyll re-
Table 2. In situ copepod data for stations where copepod herbivory experiments were conducted. In situ copepod biomass $\left(\mathrm{mg} \mathrm{C} \mathrm{m}^{-2}\right)$ standardized to a 50 to $0 \mathrm{~m}$ water column. Cop:Phyto biomass ratio compares in situ copepod biomass with 0 to $50 \mathrm{~m}$ phytoplankton biomass (copepod carbon/chlorophyll $a \times 50$, where $50=$ carbon:chl a conversion factor). Depth strata: original net-tow depths; Relative biomass: relative biomass of copepods in net tows from surface versus middle depth strata. nd: no data

\begin{tabular}{|c|c|c|c|c|c|}
\hline \multirow{2}{*}{$\begin{array}{l}\text { Water mass } \\
\text { Stn }\end{array}$} & \multirow{2}{*}{$\begin{array}{c}\text { Copepod }^{\mathrm{a}} \\
\text { biomass } \\
\text { in situ }\end{array}$} & \multirow{2}{*}{$\begin{array}{c}\text { Cop:Phyto } \\
\text { biomass } \\
\text { ratio }\end{array}$} & \multicolumn{2}{|c|}{ Depth strata (m) } & \multirow{2}{*}{$\begin{array}{l}\text { Relative } \\
\text { biomass }\end{array}$} \\
\hline & & & surface & middle & \\
\hline \multicolumn{6}{|c|}{ April, SRAW + MIX } \\
\hline 2 & 27 & 0.16 & $100-0^{c}$ & $600-100$ & 0.1 \\
\hline 22 & 143 & 0.98 & $150-0^{\mathrm{c}}$ & $300-150$ & 1.1 \\
\hline 44 & 18 & 0.14 & $100-0^{c}$ & $200-100$ & 0.3 \\
\hline \multicolumn{6}{|l|}{ April, BBW } \\
\hline 49 & 178 & 0.32 & $460-0^{\mathrm{c}}$ & nd & nd \\
\hline 27 & 1268 & 0.42 & $100-0^{c}$ & $200-100$ & 5.8 \\
\hline 40 & 242 & 0.06 & $150-0^{\mathrm{c}}$ & $300-100$ & 0.4 \\
\hline \multicolumn{6}{|c|}{ May, SRAW + MIX } \\
\hline 2 & 226 & 0.14 & $50-0$ & $100-50$ & 9.0 \\
\hline 27 & 195 & 0.12 & $150-0$ & nd & nd \\
\hline 22 & 87 & 0.08 & $150-0$ & nd & nd \\
\hline 44 & 423 & 0.04 & $75-0$ & $340-75$ & 0.7 \\
\hline 31 & 371 & 0.07 & $50-0$ & nd & nd \\
\hline \multicolumn{6}{|l|}{ May, BBW } \\
\hline 40 & 1262 & 0.14 & $50-0$ & $100-0$ & 1.4 \\
\hline 54 & 3194 & 0.13 & $50-0$ & $150-50$ & 2.1 \\
\hline \multicolumn{6}{|c|}{ June, SRAW + MIX } \\
\hline 2 & 1366 & 1.71 & $50-0$ & nd & nd \\
\hline 14 & 56 & 0.00 & $55-0$ & $220-75$ & 0.2 \\
\hline 27 & 622 & 0.06 & $30-0$ & $160-30$ & 2.2 \\
\hline 22 & 154 & 0.02 & $50-0$ & $180-50$ & 0.3 \\
\hline 31 & 173 & 0.01 & $50-0$ & $150-50$ & 0.5 \\
\hline 60 & - & nd & - & nd & nd \\
\hline \multicolumn{6}{|l|}{ June, BBW } \\
\hline $54 a$ & 3207 & 0.16 & $50-0$ & nd & nd \\
\hline 49 & 661 & 0.03 & $50-0$ & $150-50$ & 69.5 \\
\hline 40 & 887 & 0.05 & $120-0^{c}$ & nd & nd \\
\hline $54 \mathrm{~b}$ & 2143 & 0.71 & $75-0$ & $475-75$ & 2.1 \\
\hline 50 & 508 & 0.03 & $70-0$ & $270-75$ & 2.0 \\
\hline 44 & 1265 & 0.18 & $25-0$ & $250-25$ & 0.2 \\
\hline \multicolumn{6}{|c|}{ June, BBW cold } \\
\hline 68 & 1113 & 0.58 & $80-0$ & $250-80$ & 11.3 \\
\hline 82 & 511 & 0.34 & $75-0$ & nd & nd \\
\hline \multicolumn{6}{|c|}{ July, SRAW + MIX } \\
\hline 2 & 20 & 0.00 & $75-0$ & $425-75$ & 0.1 \\
\hline \multicolumn{6}{|l|}{ July, BBW } \\
\hline 68 & 1739 & 1.14 & $75-0$ & $125-75$ & 25.5 \\
\hline 50 & 1789 & 0.28 & $75-0$ & $250-75$ & 2.5 \\
\hline 44 & 1062 & 0.20 & $60-0$ & $140-60$ & 12.3 \\
\hline 1 & 839 & 0.09 & $40-0$ & nd & nd \\
\hline 40 & 373 & 0.10 & $50-0$ & $175-50$ & 2.0 \\
\hline 35 & 588 & 0.11 & $100-0$ & $350-100$ & 0.9 \\
\hline 54 & 602 & 0.26 & $80-0$ & $200-80$ & 6.6 \\
\hline
\end{tabular}

antegrated copepod carbon (50 to $0 \mathrm{~m}^{\mathrm{a}} \mathrm{mg} \mathrm{m}^{-2}$ ) calculated using data of $\mathrm{L}$. Fortier et al., Université Laval, and D. Deibel et al.

${ }^{b}$ Phytoplankton biomass estimated from chlorophyll a data provided by L. Legendre et al., Université Laval (for method see Klein et al. 2002)

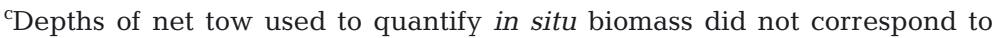
depths of 'live' tow used for experiments (see text) 


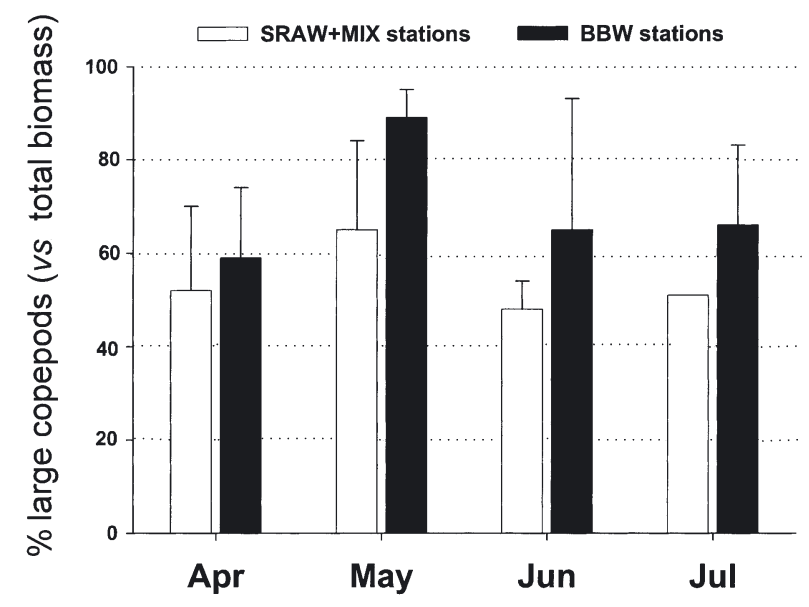

Fig. 3. Copepod biomass. Relative biomass (\% total) of 'large' copepods in situ (monthly station avg. $\pm 1 \mathrm{SD}$ ); total: biomass of large and small copepods

moval. There was a general monthly change in pellet color from brown-green in May to light or grey-green in June, then grey-green or white in July (Table 3).

We measured no overall difference in weight specific herbivory rates of SRAW + MIX versus BBW copepod assemblages (Table 3, Fig. 2g,h). Highest specific rates were measured in late May and June, when we often observed high chlorophyll a concentrations (Table 1). Initial food concentration explained $54 \%$ of the variance in weight-specific herbivory rate (Fig. 6: $\mathrm{r}^{2}=0.54$, $\mathrm{p}=0.0001, \mathrm{n}=30$; rate $\left[\mathrm{d}^{-1}\right]=0.0044( \pm 0.011)+0.020$ $( \pm 0.0035) \times t_{0} \mathrm{chl} \mathrm{a}\left[\mathrm{\mu g} \mathrm{l}^{-1}\right]$; we excluded 1 outlier from final regression analysis: Stn 54 in May).

Depths below the chlorophyll maximum were represented at 13 stations where we did a second experiment (data not shown; prey water from 60 to $125 \mathrm{~m}$, median $=95 \mathrm{~m}$ ). Only 2 of 13 showed statistically significant herbivory by copepods (Stns 27 and 31 in June); these had initial phytoplankton concentrations of 38 and $105 \mu \mathrm{g} \mathrm{C}^{-1}$. Fecal pellets were observed in these and in 2 other 'deep' experiments (initial phyto-

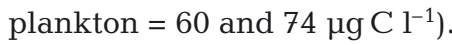

Copepod size-frequency distributions in experimental replicates were usually statistically equivalent. Because of statistical differences between a few samples, we excluded 1 'deep' experiment (April, Stn 40, $100 \mathrm{~m}$ ) and 2 bottles (1 each for June [Stn 14, $15 \mathrm{~m}$ ] and July [Stn 44, $33 \mathrm{~m}$ ]).

\section{Extrapolation of experimental to in situ herbivory rates}

Experiments were designed to represent the surface layer, which we define as the upper $50 \mathrm{~m}$ of the water column (except where we discuss the original zooplankton net tows). In fact, the average initial concentration of chlorophyll $a$ in experiments was a good predictor $\left(\mathrm{r}^{2}=0.76, \mathrm{p}<0.0001\right)$ of the in situ phytoplankton carbon concentration estimated independently using chlorophyll a profiles for the 0 to $50 \mathrm{~m}$ water column (Fig. 7). The 0 to $50 \mathrm{~m}$ water column usually incorporated the mixed-layer depth (32 of 35 stations: Y. Gratton et al. unpubl. data), and the $1 \%$ light depth (30 of 35 stations; Mei et al. 2002).

We collected experimental copepods from surface strata with relatively high fluorescence values (relative fluorescence units, RFU), when present, which we used as a general indicator of elevated food concentration. Net tow depths generally corresponded well with elevated RFU. Net tows often extended below $50 \mathrm{~m}$, especially in May and June, because elevated RFU (and extracted chlorophyll a $>1 \mu \mathrm{g} \mathrm{l}^{-1}$ ) was common below the $1 \%$ light depth. Our comparison of size-frequency data for experimental versus in situ copepod assemblages showed significant difference in most cases (results not shown). Experimental treatments generally under-represented the smaller copepod groups that were present in situ, and we sometimes over-represented intermediate size groups.

If we assume no relationship between copepod size and weight-specific herbivory rate $(b=0)$, estimates of total in situ herbivory were 0 to $164 \mathrm{mg} \mathrm{C} \mathrm{m}^{-2} \mathrm{~d}^{-1}$ (Method A: Table 4). When we include the maximum size effect tested by our model $(b=-0.3)$, which generated reasonable specific rates even for standard $1 \mathrm{~mm}$ copepods (Fig. 8), estimates of total in situ herbivory were 0 to $176 \mathrm{mg} \mathrm{C} \mathrm{m}^{-2} \mathrm{~d}^{-1}$ (Method B: Table 4). The unweighted estimates of total in situ copepod herbivory (A) were higher than the size-weighted estimates (B) for 16 stations and lower for 10 stations (max. $\pm 40 \%$ ). Median rates were (A) 20 and (B) $17 \mathrm{mg} \mathrm{C} \mathrm{m}^{-2} \mathrm{~d}^{-1}$.

Whether or not a size effect is included in our estimate of total in situ herbivory, copepods usually consumed less than $\sim 10 \%$ of daily primary production. Larger impacts $(15,55 \%$ PP) were observed after the spring bloom at southern stations (Stns 44 and 54, respectively). These were not due to high weightspecific herbivory rates, but to both a relatively high in situ biomass of copepods (602 and $2142 \mathrm{mg} \mathrm{C} \mathrm{m}^{-2}$, respectively) and relatively low daily primary production (70 and $467 \mathrm{mg} \mathrm{C} \mathrm{m}^{-2} \mathrm{~d}^{-1}$, respectively; Table 4). Rates of total in situ herbivory by copepods peaked in May for BBW stations (median $=121 \mathrm{mg} \mathrm{C} \mathrm{m}^{-2} \mathrm{~d}^{-1}$ ) and in June for SRAW + MIX stations $\left(29 \mathrm{mg} \mathrm{C} \mathrm{m}^{-2} \mathrm{~d}^{-1}\right)$; BBW stations showed generally higher total rates (Table 4 and Fig. 2i,j). Stocks of prey and predator both varied over 3 orders of magnitude; evaluated separately, each explains $50 \%$ of the variance in total daily herbivory (Model I regression: $\mathrm{p}=0.0001$, $\mathrm{df}=25$ ). 
Together, these 2 variables explained $66 \%$ of variance in total daily herbivory (adjusted $\mathrm{r}^{2}=0.66, \mathrm{p}=0.0001 ; \mathrm{df}=25 ; Y=$ $-4.5( \pm 6.2)+[0.019( \pm 0.0051) \times \mathrm{mg}$ copepod C $]+[0.0025( \pm 0.00068) \times \mathrm{mg}$ phytoplankton $\mathrm{C}_{\text {; }}$ interaction term not significant; Fig. 9).

\section{DISCUSSION}

\section{Herbivory rates}

Rates for NOW assemblages were comparable to those measured for similar species/stage groups in other cold oceans (Table 5). Although maximum chlorophyll concentrations were observed later at SRAW + MIX than at BBW stations, the overall range of weight-specific herbivory rates was similar in the 2 regions (Fig. 2g,h). Variability of specific herbivory rates for copepod assemblages within both water-mass regions may be attributed to size structure changes in both phytoplankton and copepod assemblages, varying prey concentration, and water temperature.

Booth et al. (2002) found that the general spring-to-summer pattern of phytoplankton species succession in the NOW is typical of arctic waters: in spring the bloom was dominated by ribbon-forming pennate (e.g. Fragilariopsis spp.) and chain-forming centric diatoms (e.g. Thalassiosira spp.), but by July the bloom was dominated by the small centric diatom Chaetoceros socialis (except at southeastern stations). Despite the common use of chlorophyll $a$ as a proxy for food concentration, seasonal changes in phytoplankton assemblage size structure can affect actual prey availability. Unfortunately, our chlorophyll data did not include appropriate size fractions for testing this hypothesis. Copepod size also determines the size range of prey particles available to herbivores. The size structure of copepod assemblages increased in May, as late-stage Calanus hyperboreus migrated into the surface layer, then decreased in June, when early-stage Calanus spp. copepodites emerged in great abundance (Fig. 4). There was some tendency for a smaller average body size of treatment copepods at stations where we measured higher specific herbivory rates, but there was no significant relationship (data not shown). Booth et al. (2002) examined fresh copepod fe-
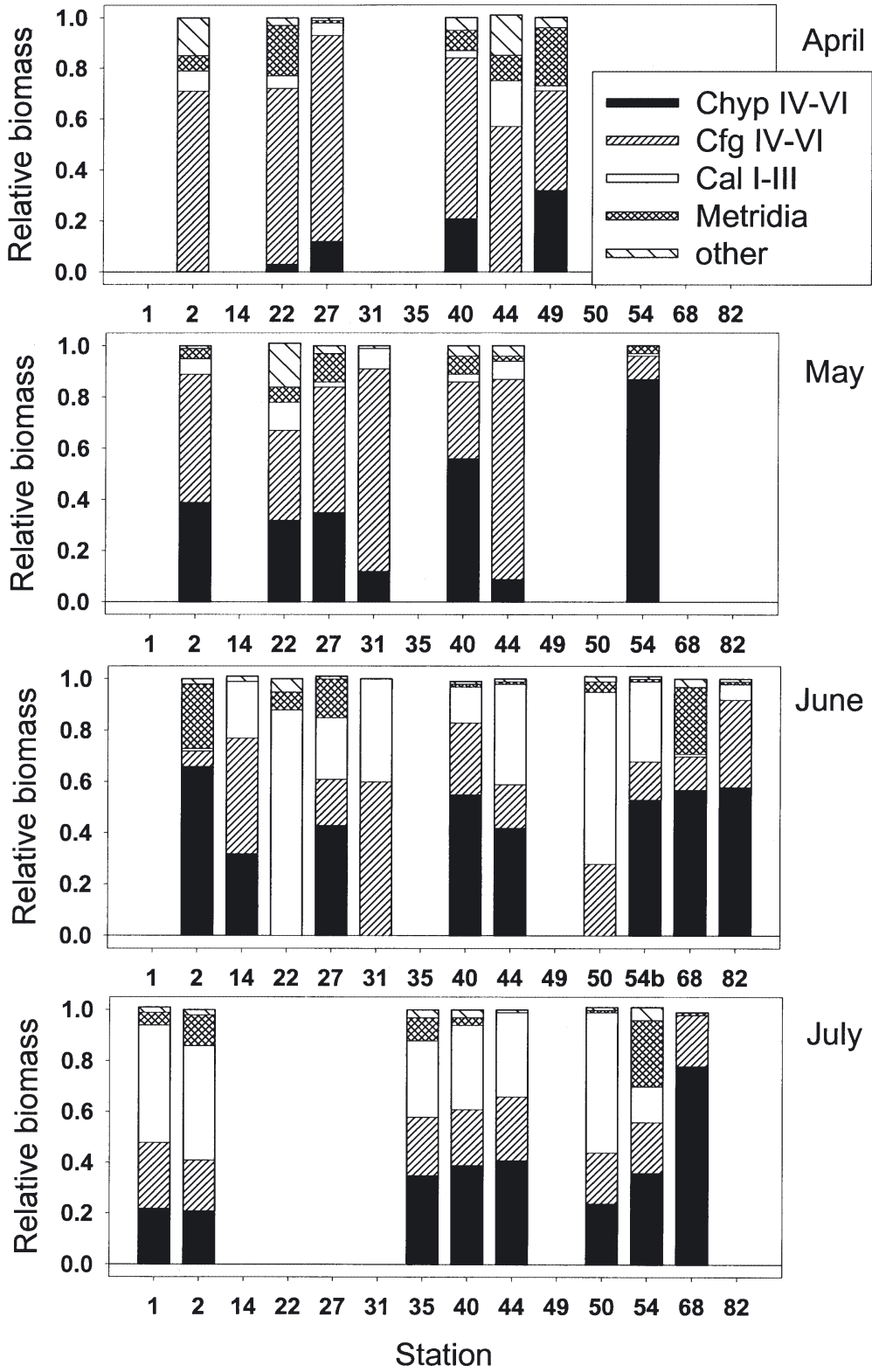

Fig. 4. Relative copepod carbon biomass (\% of total) for copepod groups in surface net-tow samples (see Table 2 for depths) at all stations where we conducted incubation experiments to determine specific herbivory rate. For June plot, Stn 54a (5 June) omitted for clarity (data were similar to those for Stn 54 in May). Summary groupings (see key) of copepods are Chyp IV-VI: Calanus hyperboreus IV-VI; Cfg IV-VI: C. finmarchicus and C. glacialis IV-VI; Cal I-III: Calanus spp. I-III; Metridia: Metridia longa. Other: others (e.g. Pseudocalanus sp., Microcalanus sp., and Oithona sp.)

cal pellets from all of the larger copepod species in July 1998; most pellets at both northern and southern stations included Chaetoceros spp. However, these data altogether do not describe how size structure changes affect grazing efficiency or selectivity, and it is not known how these factors interact with intrinsic size-related differences in specific ingestion rate. 
Table 3. Results of copepod grazing experiments in North Water Polynya (April to July 1998). General linear model (GLM) compares $24 \mathrm{~h}$ change in chlorophyll $a$ in treatment versus control bottles. L, S: large-copepod and small-copepod sieve fractions, respectively. Proportional treatment effect $=$ difference in average chlorophyll a concentration [(treatment $\left.t_{\mathrm{f}}-\mathrm{control} t_{\mathrm{f}}\right) / \mathrm{control}$ $\left.t_{\mathrm{f}}\right]_{i}$ Herbivory rate $=$ weight-specific rate $\left(\mu \mathrm{gC} \mu \mathrm{g} \mathrm{C}^{-1} \mathrm{~d}^{-1}\right) ; \mathrm{nd}=$ no data

\begin{tabular}{|c|c|c|c|c|c|c|c|c|c|}
\hline \multirow{2}{*}{$\begin{array}{l}\text { Water mass } \\
\text { Stn }\end{array}$} & \multicolumn{2}{|c|}{ Delta [chl a], avg. $\mathrm{d}^{-1}$} & \multirow{2}{*}{$\begin{array}{c}\text { Proportional } \\
\text { treatment } \\
\text { effect }\end{array}$} & \multirow{2}{*}{$\begin{array}{c}\text { GLM } \\
\text { p-value } \\
\text { if }<0.1\end{array}$} & \multicolumn{3}{|c|}{ Herbivory rate } & \multirow{2}{*}{$\begin{array}{c}\text { Fecal pellets } \\
\text { at } t_{\mathrm{f}}\end{array}$} & \multirow{2}{*}{$\begin{array}{l}\text { Fecal pellet } \\
\text { color }\end{array}$} \\
\hline & Control & Treatment & & & avg. & $\mathrm{CV}$ & $\mathrm{n}$ & & \\
\hline \multicolumn{10}{|c|}{ April, SRAW + MIX } \\
\hline $2(\mathrm{~L})$ & 0.007 & 0.007 & 0.01 & - & 0 & - & - & no & - \\
\hline (S) & & 0.004 & -0.09 & - & 0.00001 & 100 & 2 & no & - \\
\hline $22(\mathrm{~L})$ & -0.002 & -0.002 & -0.01 & - & 0.00003 & 100 & 2 & no & - \\
\hline (S) & & -0.009 & -0.15 & 0.02 & 0.0001 & 16 & 3 & no & - \\
\hline $44(\mathrm{~L})$ & 0.011 & -0.005 & -0.26 & - & 0.0002 & 80 & 2 & no & - \\
\hline (S) & & -0.010 & -0.44 & 0.08 & 0.0004 & 24 & 3 & no & - \\
\hline \multicolumn{10}{|l|}{ April, BBW } \\
\hline $49(\mathrm{~L})$ & 0.025 & 0.000 & -0.18 & - & 0.0003 & 56 & 2 & no & - \\
\hline (S) & & -0.010 & -0.31 & - & 0.0003 & 32 & 3 & no & - \\
\hline 27 & 0.014 & -0.123 & -0.34 & 0.004 & 0.0016 & 48 & 3 & no & - \\
\hline 40 & 0.392 & -0.312 & -0.39 & 0.02 & 0.0468 & 6 & 3 & no & - \\
\hline \multicolumn{10}{|c|}{ May, SRAW + MIX } \\
\hline 2 & 0.006 & -0.081 & -0.16 & - & 0.0031 & 11 & 2 & no & - \\
\hline $27(\mathrm{~L})$ & -0.006 & -0.303 & -0.52 & - & 0.0041 & 10 & 3 & no & - \\
\hline (S) & & -0.302 & -0.51 & - & 0.0152 & 4 & 3 & no & - \\
\hline 22 & 0.006 & -0.011 & -0.14 & - & 0.0041 & 39 & 3 & no & - \\
\hline 44 & 0.071 & -0.859 & -0.21 & 0.04 & 0.1027 & 12 & 3 & yes & green-brown \\
\hline 31 & 0.141 & -0.758 & -0.33 & 0.02 & 0.0779 & 28 & 3 & yes & $\begin{array}{l}\text { green-brown, } \\
\text { brown-red }\end{array}$ \\
\hline \multicolumn{10}{|l|}{ May, BBW } \\
\hline 40 & 0.827 & -1.193 & -0.50 & 0.07 & 0.0614 & 1 & 2 & yes & $\begin{array}{l}\text { brown, brown- } \\
\text { green }\end{array}$ \\
\hline 54 & 0.216 & -5.128 & -0.38 & 0.0004 & 0.0514 & 14 & 3 & yes & green-brown \\
\hline \multicolumn{10}{|c|}{ June, SRAW + MIX } \\
\hline $2(\mathrm{~L})$ & 0.012 & -0.097 & -0.34 & 0.06 & 0.0026 & 17 & 3 & no & - \\
\hline (S) & & -0.053 & -0.21 & - & 0.0575 & 58 & 3 & no & - \\
\hline 14 & 0.597 & -0.185 & -0.10 & 0.008 & 0.1404 & 33 & 3 & yes & nd \\
\hline 27 & -0.173 & -0.066 & 0.01 & - & 0 & - & - & no & - \\
\hline 22 & -0.289 & -0.806 & -0.20 & 0.1 & 0.2377 & 79 & 3 & yes & nd \\
\hline 31 & 0.249 & -0.558 & -0.17 & - & 0.1928 & 93 & 2 & yes & light olive-green \\
\hline 60 & -0.614 & -0.701 & -0.03 & - & 0 & - & - & yes & $\begin{array}{l}\text { brown-green, } \\
\text { dark grey }\end{array}$ \\
\hline \multicolumn{10}{|l|}{ June, BBW } \\
\hline $54 \mathrm{a}$ & -0.304 & -1.751 & -0.37 & - & 0.0218 & 74 & 3 & yes & nd \\
\hline 49 & -1.521 & -0.693 & 0.10 & - & 0 & - & - & yes & nd \\
\hline 40 & -0.343 & -3.502 & -0.33 & 0.05 & 0.2213 & 21 & 3 & yes & green \\
\hline $54 \mathrm{~b}$ & 0.016 & -0.656 & -0.35 & 0.004 & 0.0180 & 22 & 3 & yes & grey, grey-green \\
\hline 50 & -1.647 & -1.266 & 0.07 & - & 0 & - & - & yes & green \\
\hline 44 & 0.560 & -0.825 & -0.24 & 0.06 & 0.0571 & 9 & 3 & yes & green, light green \\
\hline \multicolumn{10}{|c|}{ June, BBW cold } \\
\hline 68 & -0.048 & -0.034 & 0.03 & - & 0 & - & - & no & - \\
\hline 82 & -0.054 & -0.053 & 0.00 & - & 0.0004 & 102 & 2 & no & - \\
\hline \multicolumn{10}{|c|}{ July, SRAW + MIX } \\
\hline 2 & -0.235 & -0.669 & -0.11 & - & 0.0379 & 85 & 2 & yes & nd \\
\hline \multicolumn{10}{|l|}{ July, BBW } \\
\hline 68 & -0.069 & -0.183 & -0.19 & - & 0.0028 & 71 & 3 & no & - \\
\hline 50 & -0.024 & -0.267 & -0.08 & - & 0.0152 & 30 & 2 & yes & green, grey \\
\hline 44 & -0.041 & -0.163 & -0.08 & - & 0.0306 & 160 & 3 & yes & green-grey, white \\
\hline 1 & -0.100 & -0.006 & 0.02 & - & 0 & - & - & yes & $\begin{array}{l}\text { grey, beige, } \\
\text { grey-green }\end{array}$ \\
\hline 40 & 0.015 & -0.133 & -0.15 & - & 0.0095 & 37 & 3 & yes & light green \\
\hline 35 & -0.469 & -0.780 & -0.15 & - & 0.0251 & 68 & 3 & yes & grey, green \\
\hline 54 & 0.440 & -0.507 & -0.49 & - & 0.0619 & 56 & 3 & yes & grey-green, white \\
\hline
\end{tabular}




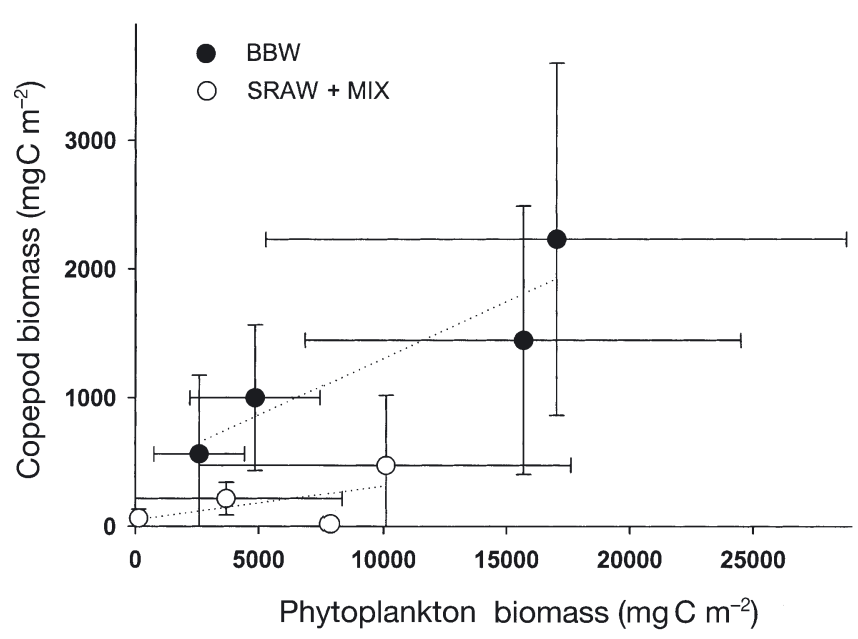

Fig. 5. Relationship between in situ copepod biomass and phytoplankton biomass. Mean $( \pm 1 \mathrm{SD})$ values calculated by month and by water-mass assignment of stations

Despite these uncontrolled sources of variance, there was a significant, positive relationship between chlorophyll a concentration and weight-specific herbivory rate (Fig. 6). This relationship represents a broad range of NOW environments, because of the 4 mo sampling period and the large area of the polynya. H. Hattori et al. (unpubl. data) also sampled NOW copepods in June and July 1998, and they found that gut-pigment content (chlorophyll $a+$ pheopigments copepod ${ }^{-1}$, after Baars \& Helling 1985) increased with increasing in situ chlorophyll a concentration $\left(\mathrm{m}^{-2}\right)$ for most biomass-dominant species/stage groups. Neither our study of assemblages nor the work of H. Hattori et al. (unpubl. data) on species/stage groups gave any evidence that ingestion rate is food-saturated, despite some of the highest in situ chlorophyll concentrations observed in arctic systems.

The temperature range observed in this study was relatively small. Herbivory rate patterns could be affected by temperature differences between the cold room and in situ, or between months in situ. However, we expect that such effects would be small (e.g. a change from -1 to $1{ }^{\circ} \mathrm{C}$ results in a $25 \%$ increase in predicted weightspecific growth rate: Huntley \& Lopez 1992). Further, the temperature of the prey-water sampling depth was usually no more than $0.5^{\circ} \mathrm{C}$ different from the 0 to $50 \mathrm{~m}$ mean (30 of 35 stations, data not shown).

\section{Total in situ herbivory rate of copepods}

The weight-specific herbivory rate explains neither the timing nor the magnitude of total copepod herbivory. Instead, total in situ herbivory rate depends on the abundance of predators and prey in combination (Fig. 9). Similar to phytoplankton and copepod bio-

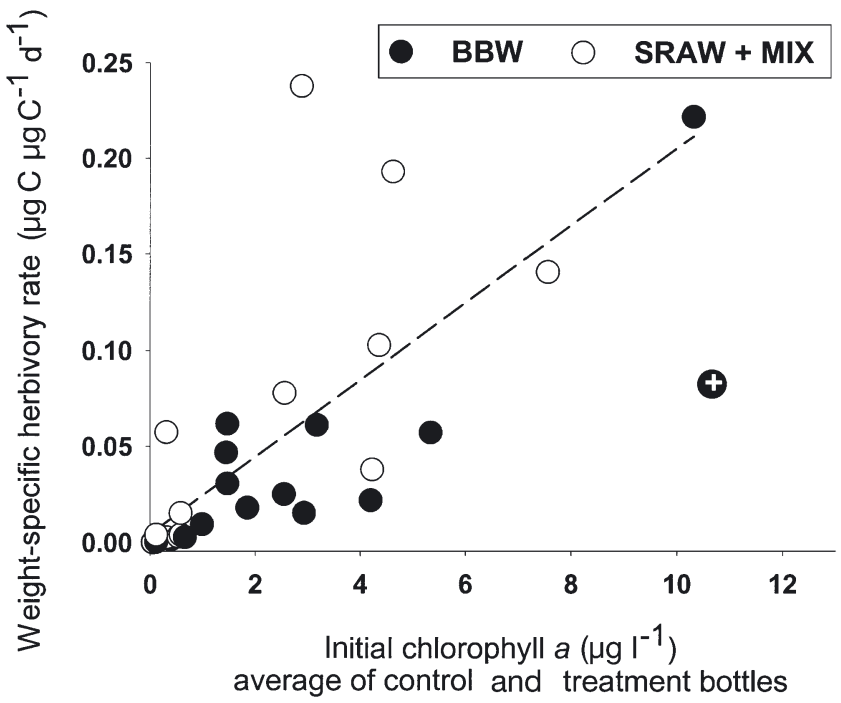

Fig. 6. Copepod herbivory rate. Relationship $\left(r^{2}=0.54, p=\right.$ 0.0001 ) between weight-specific herbivory rate and average initial $\left(t_{0}\right)$ chlorophyll a concentration in control + treatment bottles: rate $\left(\mathrm{d}^{-1}\right)=0.0044( \pm 0.011)+0.020( \pm 0.0035) \times t_{0} \mathrm{chl} \mathrm{a}$ $\left(\mu \mathrm{g}^{-1}\right)$. (+) statistical outlier from general trend

mass, total herbivory rate peaked earlier for BBW stations than for SRAW + MIX stations (Fig. 2). Although estimation methods vary, total in situ herbivory rates for the NOW are broadly similar to those determined for 4 other systems (Table 5).

Our test of the copepod size-scaling model does justify one aspect of concern as to how well experimental copepod assemblages represented in situ conditions. Each parameterization $(b=0,-0.1,-0.2,-0.3)$ generated a set

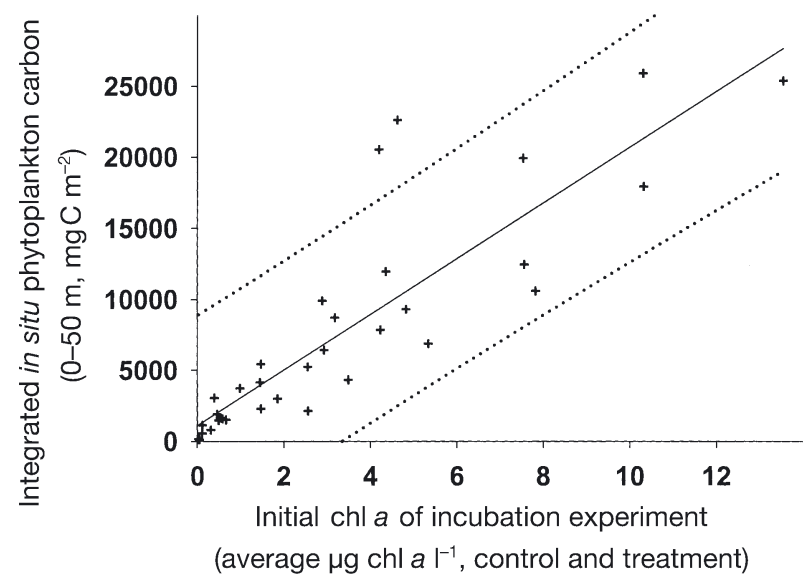

Fig. 7. Chl a concentration in experimental prey-water versus water-column concentration of phytoplankton carbon $\left(r^{2}=0.76, p<0.0001\right)$ 
of size-weighted specific rates, all of which were biologically reasonable rates for their respective copepod size class (Fig. 8). When we used these to estimate total daily herbivory rate, we did find changes at specific stations (max. $\pm 40 \%$ ). However, the overall median rate was about the same for weighted versus unweighted estimates (Table 4). Our estimate of daily grazing impact of copepods on phytoplankton changed little $( \pm 1 \% \mathrm{PP})$, even when we assumed strong size effects $(b=-0.3)$. In the NOW, variation in weight-specific herbivory rate is much less important to copepod impact than the low biomass ratio of copepods versus phytoplankton.

In the summer environment, herbivory rates based on chlorophyll removal and a carbon:chlorophyll a ratio of 50 probably do not represent total carbon ingestion by copepods as well as they do for spring experiments. Seasonal changes in fecal pellet color (Table 3) and cell-count data (P. A. Saunders et al. unpubl. data) both show that copepods were ingesting protozoan prey in late June and July, particularly at southern stations. The relative abundance of fecal pellets in the July experiments (Table 3 ) is also evidence for feeding activity, despite a statistically insignificant removal of chlorophyll. Copepod herbivory rate can also be underestimated if and when (1) copepods are consuming heterotrophic protists, and (2) heterotrophic protists are also significant herbivores (Nejstgaard et al. 1997, 2001, J. Nejstgaard pers. comm.). These conditions were met to some degree for the post-bloom ( July) experiments. However, copepod biomass was ca. 10-fold the concentration of microzooplankton in those incubations (C. Lovejoy pers. comm.), and such an inequitable ratio would help to minimize food-chain effects in the experiments (Harris et al. 2000). Also, NOW microzooplankton show relatively low specific herbivory rates (max. $0.23 \mathrm{~d}^{-1}$ total phytoplankton: H. Bussey unpubl. data). Thus, our calculations for July experiments indicate that small corrections to our estimates of specific copepod herbivory rates are appropriate for some stations (max. increase ca. 20\%), but the conclusions of this paper would not change in consequence. Increased prey diversity and lower copepod density in July experiments might accentuate variance in individual feeding behavior (Turner et al. 1993), contributing to a higher variance in specific herbivory rate among experimental replicates (July: median CV $=68 \%$, range $=30$ to $160 \%$; April to June: median $=28 \%$, range $=1$ to $102 \%$ : Table 3 ). 


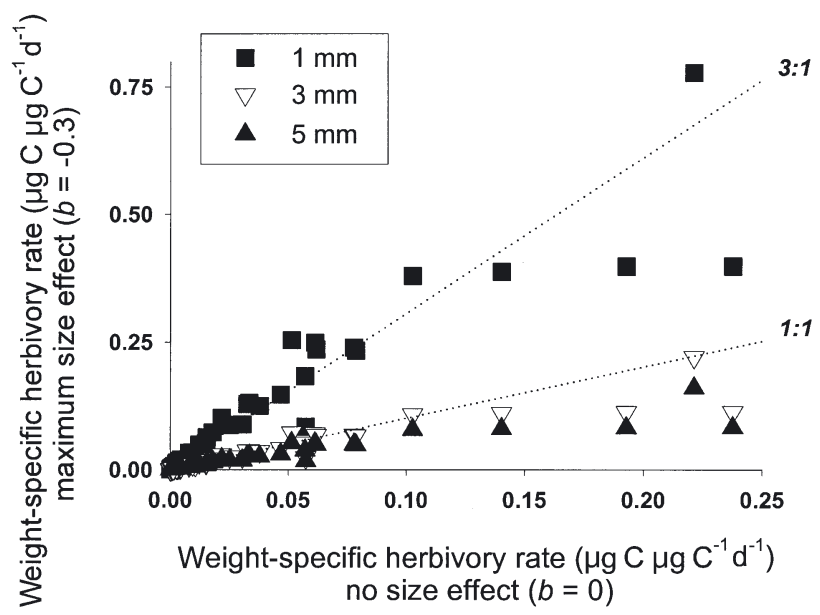

Fig. 8. Relationship between unweighted estimates of specific herbivory rate and size-weighted estimates $(b=-0.3)$ for standard-length copepods (1, 3 and $5 \mathrm{~mm})$. Size-weighted estimates were derived using size-scaling model $\mathrm{I}=\mathrm{aW} \mathrm{W}^{b}$. Guidelines (3:1 and 1:1) inserted as a visual aid

\section{Impact of copepod grazing on phytoplankton production}

In the arctic, Calanus spp. overwinter in relative abundance, suggesting the potential to consume significant portions of spring diatom production (Krause \& Trahms 1983). Our data show that copepods respond quickly to initiation of the NOW spring bloom (Fig. 2c-f), and species composition data for surface copepod samples are also consistent with upward migration of large Calanus spp. (IV to VI: Ringuette et al. 2002). However, throughout the NOW spring bloom, we found that copepod herbivory had a small impact on daily phytoplankton production, removing $<10 \%$ PP at most stations (Table 4 ). Weak coupling of phytoplankton and copepod grazers is also typical of the bloom environment of other cold seas (Table 5: Northeast Water, Davis Station), although not always (Young Sound, Disko Bay). Pre-bloom experiments measured little or no herbivory (where phytoplankton biomass $<50 \mu \mathrm{g} \mathrm{Cl}^{-1}=1 \mu \mathrm{g} \mathrm{chl} \mathrm{a}^{-1}$; Table 3). Other studies have observed a similar lower feeding threshold (e.g. Frost 1972, Gamble 1978).

The generally low impact of copepod grazers in the NOW, in comparison with other arctic systems, can be attributed to a very high primary production rate and proportionally low biomass of copepods. High productivity rates are sustained over a relatively long season (Klein et al. 2002), and the NOW spring bloom has a higher maximum biomass than most other described arctic systems (Table 5). Exceptions are the Bering Sea and Bering Strait, where there is strong advection and upwelling. Klein et al. (2002) concluded that the east- ern and northern NOW show annual primary productivity higher than predicted by the duration of openwater periods (Rysgaard et al.1999). In the north, polynya circulation may advect nutrient-rich water (Klein et al. 2002), while in the east, Tremblay et al. (2002) showed that moderate wind-mixing after initiation of the spring phytoplankton bloom could resupply nutrients and elevate productivity. In contrast to NOW phytoplankton, maximum NOW copepod biomass was similar to that of other arctic systems (Table 5), and therefore the ratio of copepods versus phytoplankton biomass was relatively small at most stations (Table 2). The weight-specific herbivory rates we measured in experiments were often as high as or higher than predictions of global empirical models for NOW temperatures (e.g. Huntley \& Lopez 1992). In this case, a biologically reasonable variation in specific herbivory rate would not affect our conclusion of low copepod impact.

As the spring phytoplankton bloom declined in 1998 (Booth et al. 2002), our estimates of total copepod herbivory showed increased impact on daily PP at 2 southern stations in late June (15 and 55\%; Table 4). At these stations (54 and 44), the greater copepod impact was due largely to decreased primary productivity rates. Klein et al. (2002) showed that reduced primary productivity is probably typical of the second half of the NOW growing season, although they cautioned that their productivity data were from 2 sampling years with seasonal differences in surface-layer chlorophyll concentration (see Bélanger et al. unpubl. data). In late August and Sep-

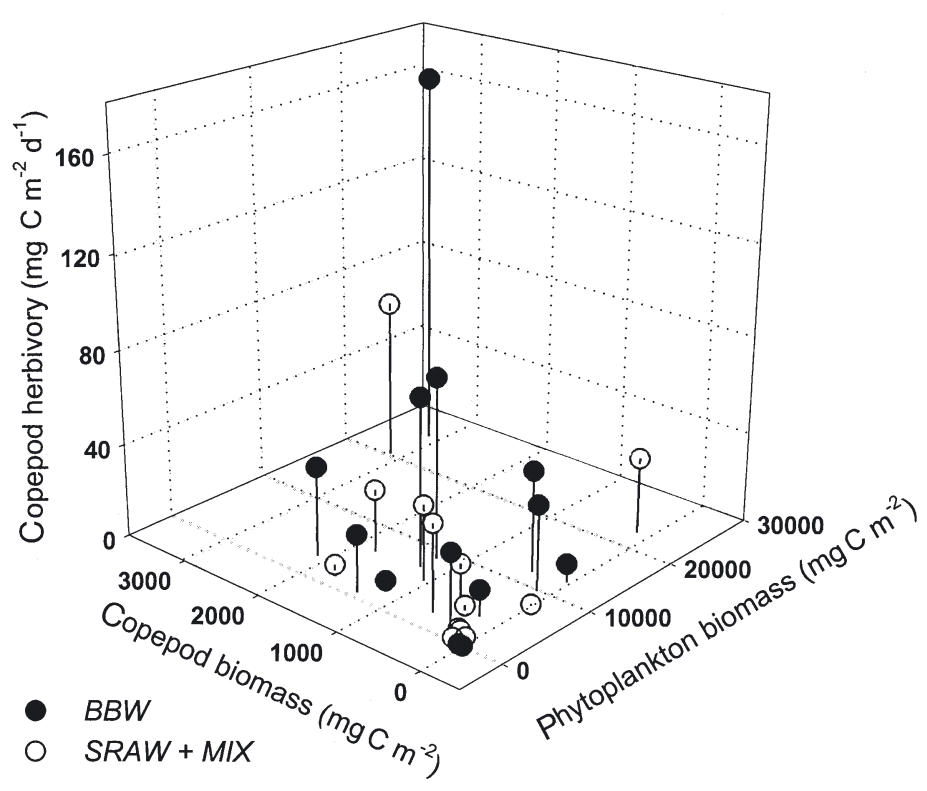

Fig. 9. Total in situ herbivory rate of copepods (no size effect) versus total in situ biomass of copepods and total in situ biomass of phytoplankton (adjusted- $\mathrm{r}^{2}=0.66, \mathrm{p}=0.0001$ ) 
Table 5. Literature data on biomass and copepod herbivory rates in polar-ocean systems (approximately -1 to $5^{\circ} \mathrm{C}$ ). PP: daily primary production; POC: particulate organic carbon stock; APP: annual primary production. Impact (\%): daily impact of copepod grazing

\begin{tabular}{|c|c|c|c|c|c|c|c|}
\hline Study site & $\begin{array}{l}\text { Temp. } \\
\left({ }^{\circ} \mathrm{C}\right)\end{array}$ & $\begin{array}{l}\text { Phytoplankton } \\
\text { biomass } \\
\left(\mathrm{mg} \mathrm{C} \mathrm{m}^{-2}\right)\end{array}$ & $\begin{array}{l}\text { Copepod } \\
\text { biomass } \\
\left(\mathrm{mg} \mathrm{C} \mathrm{m}^{-2}\right)\end{array}$ & $\begin{array}{l}\text { Copepod } \\
\text { herbivory } \\
\left(\mathrm{mg} \mathrm{C}^{-1} \mathrm{~d}^{-1}\right)\end{array}$ & $\begin{array}{l}\text { Weight-specific } \\
\text { ingestion rate } \\
\left(\mathrm{mg} \mathrm{C} \mathrm{mg} \mathrm{C}^{-1}\right. \\
\left.\mathrm{d}^{-1}\right)\end{array}$ & $\begin{array}{l}\text { Impact } \\
(\%)\end{array}$ & Source \\
\hline \multirow[t]{2}{*}{ Disko Bay, W Greenland } & $-0.5-5.5$ & $300-690$ & $1000-4600$ & $\begin{array}{l}150-575^{\mathrm{b}} \\
20-230^{\mathrm{c}}\end{array}$ & $0.10-0.19$ & $\begin{array}{l}15-85^{\mathrm{h}} \\
(\mathrm{PP})\end{array}$ & $\begin{array}{l}\text { Nielsen \& Hansen } \\
\text { (1995) }\end{array}$ \\
\hline & - & - & - & - & $\sim 0.02$ & - & Levinsen et al. (2000) \\
\hline Barents Sea & - & - & - & - & $0.005-0.54$ & - & $\begin{array}{l}\text { Tande \& Båmstedt } \\
\text { (1985) }\end{array}$ \\
\hline Davis Station, E Antarctica & -1 & - & - & - & $0.05-2.63^{g}$ & $1-5$ & Swadling et al. (1997) \\
\hline $\begin{array}{l}\text { Young Sound, } \\
\text { NE Greenland }\end{array}$ & - & $1200-2800$ & $646-2928$ & $\begin{array}{l}80-400^{\mathrm{d}} \\
79-389^{\mathrm{e}}\end{array}$ & - & $\begin{array}{l}100 \\
(\mathrm{APP})\end{array}$ & Rysgaard et al. (1999) \\
\hline $\begin{array}{l}\text { Fram Strait }(7 / 1984, \\
6 / 1988)\end{array}$ & $-1.5-3.0$ & $250-4750^{\mathrm{a}}$ & $386-4205$ & $5.4-244^{\mathrm{c}}$ & - & - & Hirche et al. (1991) \\
\hline \multicolumn{3}{|c|}{$(\mathrm{POC}$, avg. $=10)$} & $160-2160$ & $1-445^{\mathrm{c}}$ & (PC & $\begin{array}{l}0.2-53^{c} \\
\text { C, avg. }=10)\end{array}$ & Hirche et al. (1994) \\
\hline$(5-8 / 1993)$ & $-1.7-5.2$ & $59-1991$ & $79-647$ & $9-78^{d}$ & - & $\begin{array}{c}17-38^{\mathrm{d}} \\
\mathrm{PP}>5 \mu \mathrm{m})\end{array}$ & Pesant et al. (1998) \\
\hline Bering Strait & - & $<2500->10000^{\mathrm{a}}$ & - & - & - & - & Sambrotto et al. (1984) \\
\hline $\begin{array}{l}\text { NOW Polynya, } \\
\text { NW Greenland-Canada }\end{array}$ & $-1.8-0.3$ & $125-25880$ & $18-3207$ & $0.4-164^{\mathrm{f}}$ & $0.0001-0.24$ & - & This study \\
\hline $\begin{array}{l}{ }^{\mathrm{a}} \text { Our estimation from repor } \\
{ }^{\mathrm{c}} \text { Calculated from egg-proc } \\
\text { Hansen et al. }(1997) ;{ }^{\mathrm{f}} \mathrm{Calc} \\
\text { by } 3 \text { methods }\end{array}$ & $\begin{array}{l}\text { ted chloro } \\
\text { duction rat } \\
\text { culated fror }\end{array}$ & $\begin{array}{l}\text { phyll a values, ass } \\
\text { te data; }{ }^{d} \text { Based or } \\
\text { m chlorophyll rem }\end{array}$ & $\begin{array}{l}\text { suming C:ch } \\
\text { on empirical } \\
\text { moval-rate d }\end{array}$ & $\begin{array}{l}=50 ;{ }^{b} \mathrm{Cal} \\
\text { lodel of } \mathrm{Hu} \\
\mathrm{a}_{i}{ }^{g} \mathrm{Calcula}\end{array}$ & $\begin{array}{l}\text { ulated from gut } \mathrm{fl} \\
\text { ntley \& Lopez (19 } \\
\text { ed from radioisotc }\end{array}$ & $\begin{array}{l}\text { luorescence a } \\
92)_{;}{ }^{\text {eBased o }} \\
\text { ope uptake ra }\end{array}$ & $\begin{array}{l}\text { and gut turnover data; } \\
\text { on empirical model of } \\
\text { ate; }{ }^{\text {h}} \text { Range for results }\end{array}$ \\
\hline
\end{tabular}

tember 1999, regional primary production rate was 75 and $200 \%$ of the July 1998 rate, respectively, but was ca. $50 \%$ of the regional rates measured in May and June 1998 (Klein et al. 2002). Other studies of post-bloom conditions have found that daily herbivory can sometimes exceed daily primary production (Longhurst \& Head 1989, Hansen et al. 1990), but we do not have experimental data for most of the duration of NOW summer conditions.

During the NOW summer (starting late June to July), copepods face 2 major changes in available prey. One important characteristic of the summer phytoplankton is the abundance of Chaetoceros socialis in the form of very small colonies and isolated cells $(<10 \mu \mathrm{m}$ : Booth et al. 2002). Booth et al. (2002) hypothesized that C. socialis is especially important to carbon flux in the NOW versus other arctic systems because it blooms through September. A substantial biomass of early-stage Calanus spp. copepodites (I to III) appeared in June and July (14 to $88 \%$ of the total: Fig. 4), following late-winter and spring egg-production (Ringuette et al. 2002). Booth et al. (2002) observed vegetative cells of Chaetoceros socialis in July fecal pellets from dominant NOW copepod species.
Huntley (1981) showed that 5 to $10 \mu \mathrm{m}$ flagellates were consumed by Calanus finmarchicus, but not by the 2 larger Calanus (C. hyperboreus and C. glacialis) species, in the Labrador Sea; and Sieracki et al. (1998) found that North Atlantic C. finmarchicus females could obtain most of their daily carbon ration from C. socialis. Both studies suggest that $C$. socialis, when it dominates the summer diatom assemblage, could be a significant diet component of early-stage Calanus spp.

In addition to the change in diatom species and size structure, the summer prey assemblage includes substantial protozoan biomass (July 1998: Booth et al. 2002, Lovejoy et al. 2002). Levinsen et al. (2000) showed a similar increase in the abundance of flagellates, dinoflagellates, and ciliates for Disko Bay, West Greenland. Cell-count data from the NOW experiments show that copepods ingested protozoan prey in late June and July, particularly at southern stations (P. A. Saunders et al. unpubl. data). Thus, for approximately $3 \mathrm{mo}$ of the growing season, both protozoans and Chaetoceros socialis contribute to growth and survival of copepods, providing important resources to early copepodites after the decline of the large-cell diatom bloom. 
What conditions result in the relatively low biomass of copepods in the NOW? There are clearly intrinsic and temperature-related limits on potential annual population growth. There is also evidence of food-limitation for some NOW copepods: (1) this study showed a general relationship between specific herbivory rate and chlorophyll concentration; (2) Ringuette et al. (2002 and pers. comm.) reported that gonad maturation, and thus egg-production rates, of Calanus glacialis and Pseudocalanus sp. (although not of other species) are positively related to in situ chlorophyll a concentration. However, population growth is the sum of potential population increase and extrinsic mortality factors. The outstandingly abundant populations of birds in the NOW include at least 15 million breeding pairs of dovekies in the Thule area (Alle alle: Kampp et al. 2000), with 30 to 60 million pairs in the whole NOW region (Karnovsky \& Hunt 2002). A. alle consumes large Calanus spp. for much of their time in the NOW, and our calculations show reasonable agreement between the carbon requirement of the dovekie population (A. alle) and approximate production rates of $C$. hyperboreus in May and June 1998 (Karnovksy \& Hunt 2002). We speculate that the abundance of large Calanus spp. is controlled by predation in the NOW, and that populations therefore do not reach the potential abundance suggested by their large food supply. On the other hand, the egg-production of some smaller copepods in the NOW is controlled by temperature during the spring bloom (Ringuette et al. 2002), and cell size or the availability of non-phytoplankton prey may limit other small species. Vidal \& Smith (1986) came to similar conclusions for small copepod species of the middle shelf in the SE Bering Sea.

Our estimates of herbivory by copepods suggest that there is nothing unusually efficient about the coupling of copepods and spring phytoplankton production in the NOW pelagic food web, despite its rich bird and mammal fauna. In the Northeast Water Polynya (Hirche et al. 1994) and the Barents Sea (Eilertsen et al. 1989), most primary production sinks below the upper mixed layer and contributes a significant resource to benthic biota. Sedimentation rates for particulate organic carbon in the NOW were similar (Hargrave et al. 2002). However, we have not accounted for the feeding activity of other herbivores. In the NOW, copepod nauplii may graze an additional fraction of primary production (e.g. Turner et al. 2001); copepods occupying depths below the high-chlorophyll layer (e.g. Metridia longa) may use material initially generated in the euphotic layer; and the heterotrophic protozoans consumed by copepods after the spring diatom bloom (e.g. Levinsen et al. 2000) are very probably herbivorous (H. Bussey unpubl. data). Gelatinous mesozooplankton, particularly pelagic tunicates (Oikopleura spp., Fritillaria spp.) and pteropods (Limacina spp.), feed at high specific rates using a mucous 'web.' They can be important grazers, despite low population biomass. For example, Oikopleura spp., when abundant during the second half of the NOW growing season, removes more carbon from the surface layer than do copepods (Acuña et al. 2002).

\section{Summary and conclusions}

Large, late-stage copepods (Calanus spp. IV to adults: Ringuette et al. 2002) are able to respond rapidly to the spring bloom in the NOW via upward migration of overwintering individuals. The weightspecific herbivory rate of copepod assemblages was positively related to phytoplankton concentration. Seasonal peaks in daily rates of total in situ copepod herbivory corresponded with increased biomass of prey and predators in the surface layer, and these increases occurred approximately 1 mo earlier at eastern and southern stations (BBW) than at northern and western stations (SRAW + MIX). Although the biomass of copepods in the NOW was comparable to that observed in other arctic polynyas, the dominant diatoms of the bloom accumulated in very high abundance. Copepods were not sufficiently abundant to control phytoplankton biomass during the spring and early summer conditions represented by this study. We speculate that planktivory, especially by small pelagic birds, limits the abundance of large Calanus spp. Smaller copepod species may not respond to the high phytoplankton production of the NOW owing to greater limitation by cold temperature, more limited availability of small or non-phytoplankton prey particles, or both.

Acknowledgements. This work would not have been possible without the interest and skills of the officers and crew of the Canadian Coast Guard Service icebreaker 'Pierre Radisson'. The experiments required the teamwork, consideration and hard work of many NOW colleagues, including M. Fortier, H. Hattori, L. Létourneau, J. Michaud, L. Michaud, N. Nagao, S. Plourde, M. Ringuette and M. Robert. E. Hatfield analysed the fluorometry samples from experiments. The summary of monthly water-mass distribution was provided as core project data by J.-É. Tremblay et al., McGill University, Montréal. Raw CTD data were processed by B. von Hardenberg, Institute of Ocean Sciences; the $1 \mathrm{~m}$ interpolated values were provided by Y. Gratton, INRS-ETE. In situ chlorophyll profile data and daily primary productivity rates were provided as core project data by L. Legendre et al., Université Laval, Québec. In situ copepod abundances were quantified in collaboration with L. Fortier, Université Laval. T. Avery and R. C. Tian contributed to data analysis. C. Cull, K. Pike, and C. White helped with data management. This paper benefited from improvements suggested by Y. Gratton, Z. P. Mei, M. Ringuette, and 4 anonymous reviewers. Funding for the project was provided to M. R. Anderson, D.D., and R.B.R. as part of the International North 
Water Polynya program, by a grant from the National Science and Engineering Research Council Canada to L. Fortier, Université Laval. Additional support was provided by an NSERC Research Grant to D.D. This study is a contribution to the International North Water Polynya Project. This paper is a contribution of the Ocean Sciences Centre, Memorial University.

\section{LITERATURE CITED}

Acuña JL, Deibel D, Saunders PA, Booth B, Hatfield E, Klein B, Mei ZP, Rivkin R (2002) Phytoplankton ingestion by appendicularians in the North Water. Deep-Sea Res Part II 49:5101-5115

Baars MA, Helling GR (1985) Methodological problems in the measurement of phytoplankton ingestion rate by gut fluorescence. Hydrobiol Bull 19:81-88

Bâcle J, Carmack EC, Ingram RG (2002) Water column structure and circulation under the North Water during spring transition: April-July 1998. Deep-Sea Res Part II 49: 4907-4925

Bathmann UV, Noji TT, von Bodungen B (1990) Copepod grazing potential in late winter in the Norwegian Sea - a factor in the control of spring phytoplankton growth? Mar Ecol Prog Ser 60:225-233

Bautista B, Harris RP, Tranter PRG, Harbour D (1992) In situ copepod feeding and grazing rates during a spring bloom dominated by Phaeocyctis sp. in the English Channel. J Plankton Res 14:691-703

Booth BC, Larouche P, Bélanger S, Amiel D, Klein B, Mei ZP (2002) Dynamics of Chaetoceros socialis blooms in the North Water. Deep-Sea Res Part II 49:5003-5025

Dale T, Bagøien E, Melle W, Kaartvedt S (1999) Can predator avoidance explain varying overwintering depth of Calanus in different oceanic water masses? Mar Ecol Prog Ser 179:113-121

Eilertsen HC, Tande KS, Nøst Hegseth E (1989) Potential of herbivorous copepods for regulating the spring phytoplankton bloom in the Barents Sea. Rapp. P-V Réun Cons Int Explor Mer 188:154-163

Frost BW (1972) Effects of size and concentration of food particles on the feeding behavior of the marine planktonic copepod Calanus pacificus. Limnol Oceanogr 17:805-815

Gamble JC (1978) Copepod grazing during a declining spring phytoplankton bloom in the northern North Sea. Mar Biol 49:303-315

Gowen RJ, McCullough G, Kleppel GS, Houchin L, Elliott P (1999) Are copepods important grazers of the spring phytoplankton bloom in the western Irish Sea? J Plankton Res 21:465-483

Hansen B, Berggreen UC, Tande KS, Eilertsen HC (1990) Post-bloom grazing by Calanus glacialis, C. finmarchicus and C. hyperborealis in the region of the Polar Front, Barents Sea. Mar Biol 104:5-14

Hansen PJ, Bjornsen PK, Hansen BW (1997) Zooplankton grazing and growth: scaling within the $2-2000 \mu \mathrm{m}$ body size range. Limnol Oceanogr 42:687-704

Hargrave BT, Walsh ID, Murray DW (2002) Seasonal and spatial patterns in mass and organic matter sedimentation in the North Water. Deep-Sea Res Part II 49:5227-5244

Harris R, Wiebe P, Lenz J, Skjoldal HR, Huntley M (2000) ICES zooplankton methodology manual. Academic Press, San Diego

Hirche HJ, Baumann MEM, Kattner G, Gradinger R (1991) Plankton distribution and the impact of copepod grazing on primary production in Fram Strait, Greenland Sea. J Mar Syst 2:477-494
Hirche HJ, Hagen W, Mumm N, Richter C (1994) The Northeast Water Polynya, Greenland Sea. III. Meso- and macrozooplankton distribution and production of dominant herbivorous copepods during spring. Polar Biol 14:491-503

Huntley M (1981) Nonselective, nonsaturated feeding by three calanoid copepod species in the Labrador Sea. Limnol Oceanogr 26:831-842

Huntley ME, Lopez MDG (1992) Temperature-dependent production of marine copepods: a global synthesis. Am Nat 140:201-242

Kampp K, Falk K, Pedersen CE (2000) Breeding density and population of little auks (Alle alle) in a northwest Greenland colony. Polar Biol 23:517-521

Karnovsky NJ, Hunt GL Jr (2002) Estimation of carbon flux to dovekies (Alle alle) in the North Water. Deep-Sea Res Part II 49:5117-5130

Klein B, LeBlanc B, Mei ZP, Beret R and 12 others (2002) Phytoplankton biomass, production and potential export in the North. Deep-Sea Res Part II 49:4983-5002

Knap A, Michels A, Close A, Ducklow H, Dickson A (eds) (1996) Protocols for the Joint Global Ocean Flux Study (JGOFS) core measurements. JGOFS Report Nr. 19. Reprint of the IOC Manuals and Guides No. 29, UNESCO, Paris 1994

Krause M, Trahms J (1983) Zooplankton dynamics during FLEX > 76. In: Sündermann J, Lenz W (eds) North Sea dynamics. Springer-Verlag, Berlin, p 632-661

Levinsen H, Turner JT, Nielsen TG, Hansen BW (2000) On the trophic coupling between protists and copepods in arctic marine ecosystems. Mar Ecol Prog Ser 204:65-77

Longhurst A, Head E (1989) Algal production and variable herbivore demand in Jones Sound, Canadian High Arctic. Polar Biol 9:281-286

Lovejoy C, Legendre L, Martineau MJ, Bacle J, von Quillfeldt $\mathrm{CH}$ (2002) Distribution of phytoplankton and other protists in the North Water. Deep-Sea Res Part II 49:5027-5047

Mei ZP, Legendre L, Gratton Y, Tremblay JE and 8 others (2002) Physical control of spring-summer phytoplankton dynamics in the North Water, April-July 1998. Deep-Sea Res Part II 49:4959-4982

Nejstgaard JC, Gismervik I, Solberg PT (1997) Feeding and reproduction by Calanus finmarchicus, and microzooplankton grazing during mesocosm blooms of diatoms and the coccolithophore Emiliania huxleyi. Mar Ecol Prog Ser 147:197-217

Nejstgaard JC, Naustvoll LJ, Sazhin A (2001) Correcting for underestimation of microzooplankton grazing in bottle incubation experiments with mesozooplankton. Mar Ecol Prog Ser 221:59-75

Nielsen TG, Hansen B (1995) Plankton community structure and carbon cycling on the western coast of Greenland during and after the sedimentation of a diatom bloom. Mar Ecol Prog Ser 125:239-257

Nielsen TG, Richardson K (1989) Food chain structure of the North Sea plankton communities: seasonal variations of the role of the microbial loop. Mar Ecol Prog Ser 56:75-87

Pesant S, Legendre L, Gosselin M, Ashjian C and 8 others (1998) Pathways of carbon cycling in the euphotic zone: the fate of large-sized phytoplankton in the Northeast Water. J Plankton Res 20:1267-1291

Ringuette M, Fortier L, Fortier M, Runge J, Bélanger S, Larouche P, Weslawski JM, Kwasniewski S (2002) Advanced recruitment and accelerated population development in Arctic calanoid copepods of the North Water. Deep-Sea Res Part II 49:5081-5099

Rysgaard S, Nielsen TG, Hansen BW (1999) Seasonal variation in nutrients, pelagic primary production and grazing 
in a high-Arctic coastal marine ecosystem, Young Sound, Northeast Greenland. Mar Ecol Prog Ser 179:13-25

Sambrotto RN, Goering JJ, McRoy CP (1984) Large yearly production of phytoplankton in the western Bering Strait. Science 225:1147-1150

SAS Institute (1990) SAS/STAT user's guide, Vol 2, version 6, 4 th edn. SAS Institute, Cary, NC

Sieracki ME, Gifford DJ, Gallager SM, Davis CS (1998) Ecology of a Chaetoceros socialis Lauder patch on Georges Bank: distribution, microbial associations, and grazing losses. Oceanography 11:30-35

Sokal RR, Rohlf FJ (1995) Biometry: the principles and practice of statistics in biological research, 3rd edn. WH Freeman \& Co, New York

Stirling I (1997) The importance of polynyas, ice edges, and leads to marine mammals and birds. J Mar Syst 10:9-21

Swadling KM, Gibson JEA, Ritz DA, Nichols PD, Hughes DE (1997) Grazing of phytoplankton by copepods in eastern Antarctic coastal waters. Mar Biol 128:39-48

Tande KS, Båmstedt U (1985) Grazing rates of the copepods Calanus glacialis and C. finmarchicus in arctic waters of

Editorial responsibility: Otto Kinne (Editor),

Oldendorf/Luhe, Germany the Barents Sea. Mar Biol 87:251-258

Tidmarsh WG (1973) The Copepoda (Calanoida, Cyclopoida) of northern Baffin Bay and southern Nares Strait: their distribution and aspects of their biology. MSc thesis, Marine Sciences Centre, McGill University, Montreal

Tremblay JE, Gratton Y, Minnett P, Fauchot J, Price NM (2002) Climatic and oceanic forcing of new, net, and diatom production in the North Water. Deep-Sea Res Part II 49:4927-4946

Turner JT, Tester PA, Strickler JR (1993) Zooplankton feeding ecology: a cinematographic study of animal-to-animal variability in the feeding behavior of Calanus finmarchicus. Limnol Oceanogr 38:255-264

Turner JT, Levinsen H, Nielsen TG, Hansen BW (2001) Zooplankton feeding ecology: grazing on phytoplankton and predation on protozoans by copepod and barnacle nauplii in Disko Bay, West Greenland. Mar Ecol Prog Ser 221: 209-219

Vidal J, Smith SL (1986) Biomass, growth, and development of populations of herbivorous zooplankton in the southeastern Bering Sea during spring. Deep-Sea Res 33:523-556

Submitted: November 12, 2001; Accepted: April 29, 2003

Proofs received from author(s): September 23, 2003 